\title{
6. NATURE AND RECORD OF LATE MIOCENE MASS-FLOW DEPOSITS FROM THE LAU-TONGA FOREARC BASIN, TONGAN PLATFORM (HOLE 840B) ${ }^{1}$
}

\author{
Reidulv Bøe ${ }^{2}$
}

\begin{abstract}
The sedimentary sequence recovered at Site 840 , on the Tonga frontal-arc platform, is $597.3 \mathrm{~m}$ thick and is subdivided into three lithostratigraphic units. The lowermost, late Miocene Unit III is $336.8 \mathrm{~m}$ thick and consists of a sequence of volcaniclastic mass-flow deposits (predominantly turbidites) interbedded with pelagic/hemipelagic deposits.

Unit III was deposited in the forearc basin of the Lau volcanic arc, probably on a slope dominated by mass flows that built eastward from the ridge front and across the forearc. Upward through the unit a thinning and fining of individual turbidites takes place, interpreted to reflect a reduced sediment supply and a change from large to smaller flows. Decreasing volcanic activity with time is inferred from a decrease in coarse-grained volcaniclastic content in the upper part of the unit. The majority of the turbidites show the typical Bouma-type divisions, although both high-and low-density turbidity currents are inferred. High-density turbidity currents were especially common in the lower part of the unit.

Geochemical analyses of detrital glass lie mainly in the low-K tholeiite field with a compositional range from basalt to rhyolite. A coherent igneous trend indicates derivation from a single volcanic source. This source was probably situated on the rifted part of the Lau-Tonga Ridge, within the present Lau backarc basin. The initial opening of the Lau Basin may have been around 6.0 m.y. ago. The onset of more extensive rifting, approximately $5.6 \mathrm{~m} . \mathrm{y}$. ago, is reflected in an increase in the silica content of volcanic glass. At the boundary toward Unit II, at approximately $5.25 \mathrm{Ma}$, an influx of thicker bedded and coarser grained volcaniclastic material is interpreted to reflect increasing volcanism and tectonism during the final breakup of the Lau-Tonga Ridge.
\end{abstract}

\section{INTRODUCTION}

The Tonga Ridge lies along the boundary between the Indo-Australia and Pacific plates in the southwest Pacific. The Lau-Tonga region is divisible into three morphotectonic elements (Karig, 1970; Malahoff et al., 1982) (Fig. 1). Extending from the Tonga Trench, these are (1) the Tonga Ridge, constituting the forearc (Tonga Platform) and active arc (Tofua Arc); (2) the Lau Basin, representing the actively spreading backarc basin; and (3) the Lau Ridge, forming the remnant arc.

The formation of the Lau Basin was initiated approximately 6.0 m.y. ago (Parson, Hawkins, Allan, et al., 1992). Following the final breakup of the Lau-Tonga Ridge at approximately $5.25 \mathrm{Ma}$, the Tonga Ridge developed into a carbonate platform with low sediment accumulation rates, approximately 5.1 m.y. ago.

Before the initiation of rifting and backarc spreading in the Lau Basin, the Lau and Tonga ridges formed a single magmatic arc/forearc succession (Packham, 1978; Hawkins et al., 1984). The lower part of this succession, with a record ranging from the late Eocene/early Oligocene, was recovered on the inner trench wall, at Site 841 . Throughout the Miocene discontinuous, though extensive, deposition of volcaniclastics and associated pelagic/hemipelagic sediments occurred in the forearc region of the Lau Ridge, beneath the Tonga frontal-arc platform (Scholl et al., 1985; Herzer and Exon, 1985). At Site 840 drilling ended in late Miocene volcaniclastic and pelagic deposits that are approximately $6.55 \mathrm{~m}$.y. old.

The purpose of this report is to describe and interpret the late Miocene mass-flow sequence (Unit III) (Parson, Hawkins, Allan, et al., 1992) at Site 840. Chemical analyses indicate the source area of volcaniclastic grains, and the sedimentary environment will be interpreted as a function of depositional processes and regional setting.

Site 840 is located on the west flank of the Tonga Platform at $22^{\circ} 13^{\prime} \mathrm{S}, 175^{\circ} 44.9^{\prime} \mathrm{W}$, approximately $45 \mathrm{~km}$ east-northeast of 'Ata

\footnotetext{
'Hawkins, J., Parson, L., Allan, J., et al., 1994. Proc. ODP, Sci. Results, 135: College Station, TX (Ocean Drilling Program).

${ }^{2}$ Geological Survey of Norway, Leiv Eirikssons vei 39, N-7002 Trondheim, Norway.
}

Island (Fig. 1). At this site the platform is about $60 \mathrm{~km}$ wide at the $1000-\mathrm{m}$ isobath. The site water depth is $743.3 \mathrm{~m}$, deepening to more than $10,000 \mathrm{~m}$ eastward (Tonga Trench), and to approximately 2500 $\mathrm{m}$ westward (Lau Basin). Toward the west the depth increase is interrupted by the linear chain of seamounts and volcanoes of the Tofua Arc.

\section{THE SEDIMENTARY SUCCESSION}

The sedimentary succession recovered at Site 840 is $597.3 \mathrm{~m}$ thick, and is subdivided into three units (Parson, Hawkins, Allan, et al., 1992). Unit I (0-109.98 m below seafloor [mbsf]) consists of nannofossil oozes, vitric silts, vitric sands, and pumiceous gravels. Unit II (109.98-260.5 mbsf) has three depositional cycles, fining upward from predominantly unlithified pumiceous gravels into predominantly lithified nannofossil chalk, though vitric siltstones and vitric sandstones are also common.

Unit III (260.5-597.3 mbsf; approximately 5.25-6.55 Ma), which is the subject of this contribution, consists of a lithified sequence of volcaniclastic turbidites of vitric and volcaniclastic siltstone and sandstone, interbedded with highly bioturbated silty nannofossil mixed sedimentary rocks and calcareous claystones. In the lower part of the unit, beds of volcaniclastic breccia and volcanic conglomerate are also present (Fig. 2). The turbidites are usually dominated by either sandstone or siltstone, but gradation from sandstone upward into siltstone is common. The majority of the turbidites exhibit sharp, planar basal surfaces, but undulating, scoured basal surfaces and surfaces with load casts also occur.

Downward through Unit III a thickening of individual turbidites was observed (Fig. 3), and both the average and the maximum grain size of clasts in the turbidites increase. Above $500 \mathrm{mbsf}$, the average thickness of turbidites is $23 \mathrm{~cm}$. Below this depth, the average thickness is $59 \mathrm{~cm}$, with a maximum recorded bed thickness of $2.4 \mathrm{~m}$. The pelagic intervals show no systematic variation in bed thickness vs. depth. Superimposed on the overall upward-fining sequence, several mesoscopic upward-fining and -thinning and upward-coarsening and -thickening cycles, varying from a few meters up to $50 \mathrm{~m}$ in thickness, 


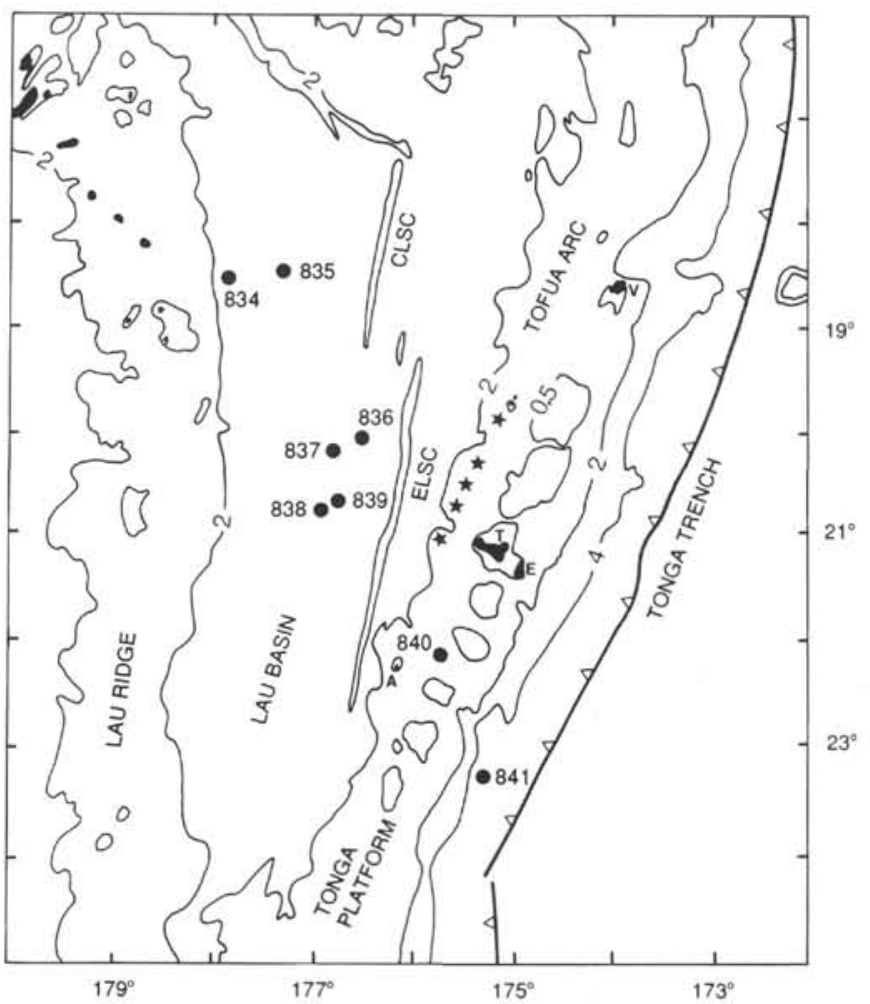

Figure 1. Regional setting for the Leg 135 drill sites showing the major geological features of the Lau Basin and the Tonga Platform. Contour interval in kilometers. Islands include $\mathrm{T}=$ Tongatapu, $\mathrm{E}=\mathrm{'}^{\mathrm{Eua}}, \mathrm{V}=\mathrm{Vava}{ }^{\prime} \mathrm{u}$, and $\mathrm{A}=$ 'Ata. The locations of the Central Lau (CLSC) and Eastern Lau (ELSC) spreading centers are shown. Stars indicate some of the active volcanoes of the Tofua Arc.

were recognized (Figs. 2-3). In the upper part of the sequence, the limit of data resolution is low because of poor recovery.

\section{Unit III Sedimentary Facies Descriptions}

The deposits of Unit III are grouped in four facies categories, based on texture, structure, and composition: (1) silty nannofossil mixed sedimentary rock and calcareous claystone, (2) vitric and volcaniclastic siltstone, (3) vitric and volcaniclastic sandstone, and (4) volcaniclastic breccia and volcanic conglomerate.

Facies 1 (Table 1) consists of light gray to gray silty nannofossil mixed sedimentary rocks. Foraminifers, within some intervals, may constitute up to $15 \mathrm{vol} \%$. Clay content increases downward, and below Core 135-840B-59X (ca. 560 mbsf) the sediment is a calcareous claystone. The pelagic sediment is frequently heavily bioturbated (Fig. 4).

Facies 2 is the most common facies of Unit III. It consists of light gray to dark gray vitric and volcaniclastic siltstone, in upward-fining beds $1-170 \mathrm{~cm}$ thick (average thickness ca. $20 \mathrm{~cm}$ ). The beds are commonly bioturbated, especially where they are overlain by $\mathrm{Fa}$ cies 1 . Convoluted intervals, $3-85 \mathrm{~cm}$ thick, with water-escape pipes (Fig. 4), microfaults, or overturned foresets (Figs. 5-6) are common. Convolution is frequently confined within thinner layers, although entire siltstone/sandstone intervals may be convoluted. Facies 2 can be subdivided into (1) normally graded, but otherwise structureless siltstone (Subfacies 2a); (2) trough cross-stratified siltstone (Subfacies 2b); (3) planar, wavy, wedge-planar, and lenticular laminated siltstone (Subfacies 2c); and (4) trough cross-laminated siltstone (Subfacies 2d) (Table 1).

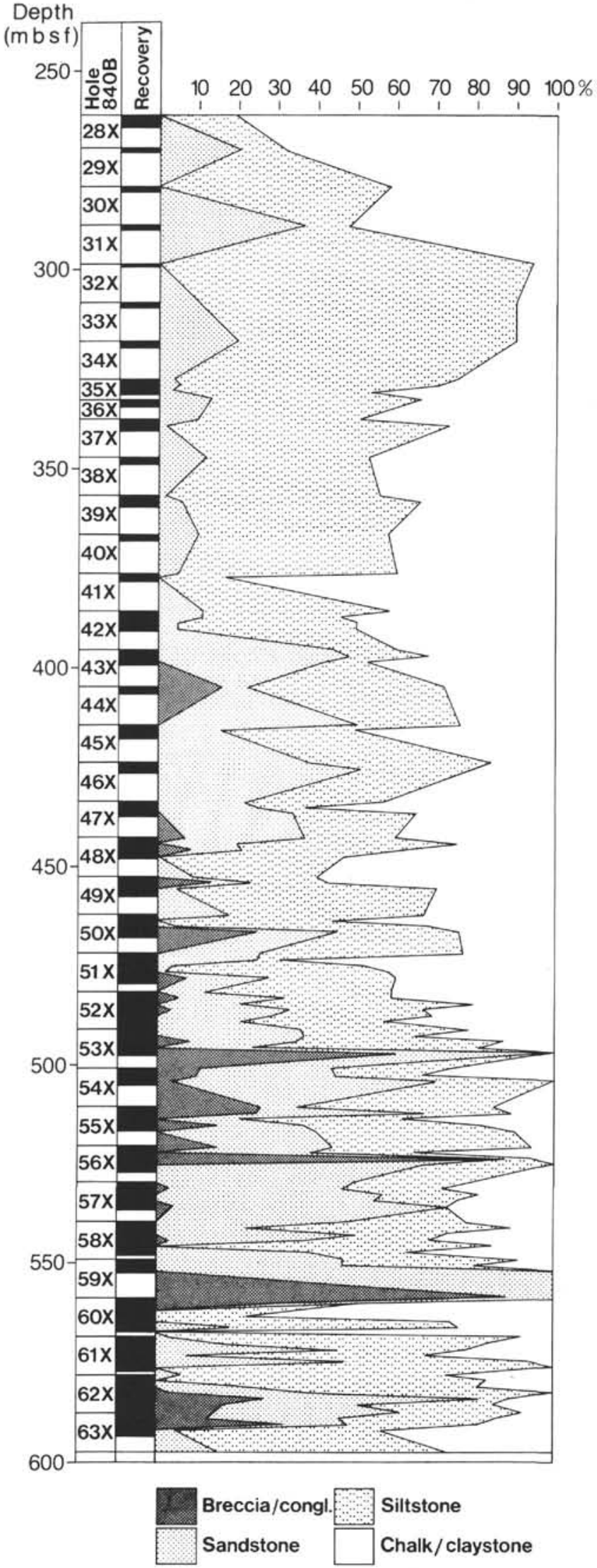

Figure 2. Textural variation of Unit III. Percentages of the four major lithologies (Facies 1-4) are calculated for each section of core. Recovered intervals are shown in black. 


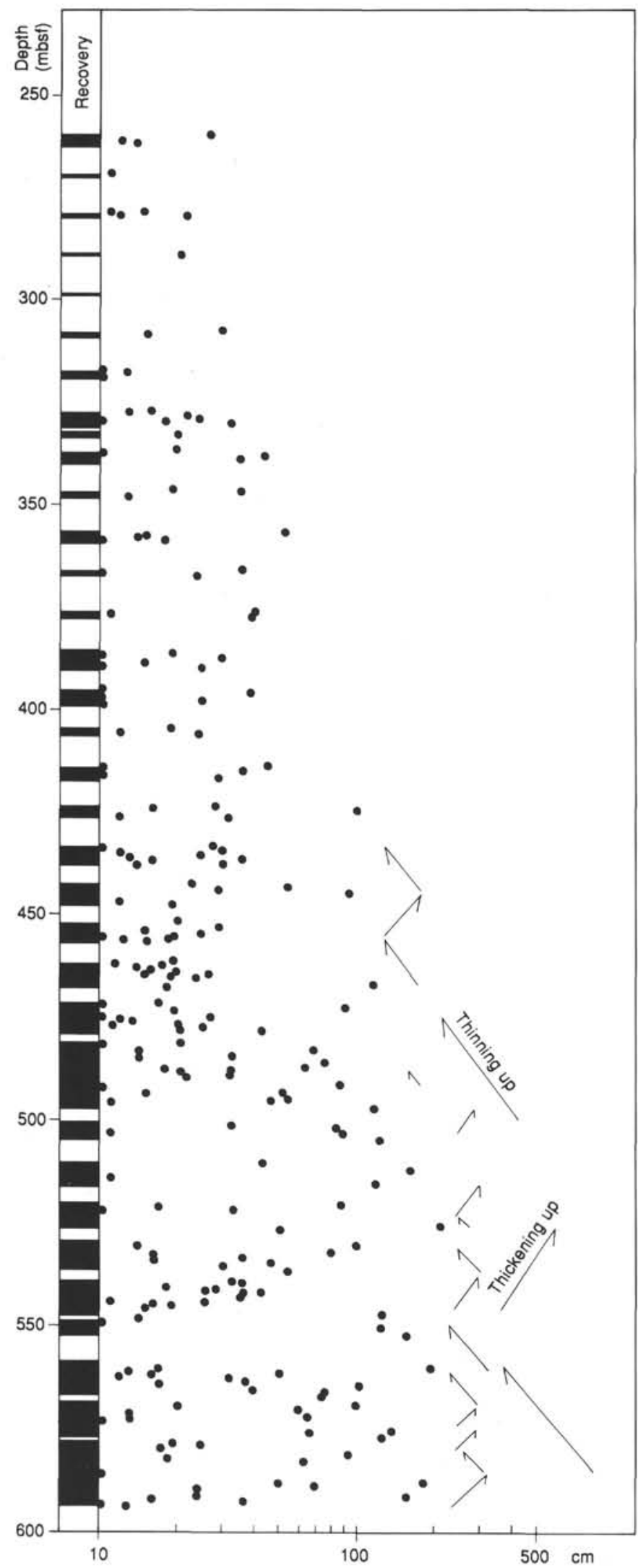

Figure 3. Variation of turbidite thickness vs. depth within Unit III. Only mass flows thicker than $10 \mathrm{~cm}$ are plotted. Some of the mesoscopic upward-thinning and -thickening cycles are shown. Note general upward-thinning throughout the unit. Also note logarithmic thickness scale. Recovered intervals are shown in black.
Table 1. Characteristics of the various facies types of Unit III, Hole 840B.

\begin{tabular}{|c|c|c|c|}
\hline $\begin{array}{l}\text { Facies } \\
\text { or } \\
\text { subfacies }\end{array}$ & $\begin{array}{l}\text { Bed thickness } \\
\quad(\mathrm{cm}) \\
\text { (average in } \\
\text { parentheses) }\end{array}$ & Components & Remarks \\
\hline 1 & $\begin{array}{l}1-90 \\
(16)\end{array}$ & $\begin{array}{l}24 \%-50 \% \mathrm{CaCO}_{3} \\
30 \%-40 \% \text { vitric } \\
\text { silt; } 5 \%-70 \% \text { clay. } \\
\text { Scattered sand- } \\
\text { sized pumice } \\
\text { grains. }\end{array}$ & $\begin{array}{l}\text { Heavily bioturbated and } \\
\text { homogenized. Faint lamination } \\
\text { caused by thin layers of vitric } \\
\text { siltstone. Increasing clay } \\
\text { content downward. }\end{array}$ \\
\hline $2 \mathrm{a}$ & $\begin{array}{l}1-50 \\
(3)\end{array}$ & $\begin{array}{l}\text { Vitric and } \\
\text { volcaniclastic silt. }\end{array}$ & $\begin{array}{l}\text { Scattered pumice clasts }<2 \mathrm{~cm} \text { in } \\
\text { diameter. }\end{array}$ \\
\hline $2 b$ & $\begin{array}{l}1-20 \\
(10)\end{array}$ & $\begin{array}{l}\text { Same as Subfacies } \\
2 \mathrm{a} \text {. }\end{array}$ & Uncommon facies type. \\
\hline $2 \mathrm{c}$ & $\begin{array}{l}1-100 \\
(12)\end{array}$ & $\begin{array}{l}\text { Same as Subfacies } \\
2 \mathrm{a} \text {. }\end{array}$ & $\begin{array}{l}\text { Planar lamination most common. } \\
\text { Lenticular lamination relatively } \\
\text { uncommon. Both thin and } \\
\text { thick laminae. }\end{array}$ \\
\hline $2 d$ & $\begin{array}{c}1-15 \\
(5)\end{array}$ & $\begin{array}{l}\text { Same as Subfacies } \\
\text { 2a. }\end{array}$ & $\begin{array}{l}\text { Climbing ripple lamination in } \\
\text { beds }<5 \mathrm{~cm} \text { thick sporadically } \\
\text { developed. }\end{array}$ \\
\hline $3 \mathrm{a}$ & $\begin{array}{c}1-25 \\
(8)\end{array}$ & $\begin{array}{l}\text { Fine- to very coarse- } \\
\text { grained vitric and } \\
\text { volcaniclastic } \\
\text { sand. Commonly } \\
\text { conglomeratic. }\end{array}$ & $\begin{array}{l}\text { May be conglomeratic, especially } \\
\text { at the base of beds. Scattered } \\
\text { pumice clasts }<2 \mathrm{~cm} \text { in diameter }\end{array}$ \\
\hline $3 b$ & $\begin{array}{c}1-15 \\
(8)\end{array}$ & $\begin{array}{l}\text { Same as Subfacies } \\
\text { 3a. }\end{array}$ & Uncommon facies type. \\
\hline $3 \mathrm{c}$ & $\begin{array}{l}1-80 \\
(24)\end{array}$ & $\begin{array}{l}\text { Same as Subfacies } \\
3 \mathrm{a} \text {. }\end{array}$ & $\begin{array}{l}\text { Planar lamination most common. } \\
\text { Lenticular lamination occurs } \\
\text { sporadically. Both thin and } \\
\text { thick laminae occur. Within } \\
\text { beds the various lamination } \\
\text { types alternate. In the coarser } \\
\text { grained sandstone beds, planar } \\
\text { lamination may grade into } \\
\text { planar stratification, especially } \\
\text { near the base. }\end{array}$ \\
\hline $3 \mathrm{~d}$ & $\begin{array}{c}1-25 \\
(7)\end{array}$ & $\begin{array}{l}\text { Same as Subfacies } \\
\text { 3a. }\end{array}$ & \\
\hline 4 & $\begin{array}{c}1-195 \\
(38)\end{array}$ & $\begin{array}{l}\text { Clasts of gray } \\
\text { pumice dominate, } \\
\text { but also darker } \\
\text { colored pumice } \\
\text { and scoriaceous } \\
\text { clasts. Matrix of } \\
\text { medium- to very- } \\
\text { coarse-grained } \\
\text { sandstone. }\end{array}$ & $\begin{array}{l}\text { Structureless, planar stratified, or, } \\
\text { more rarely, cross-stratified. } \\
\text { Normal grading common, but } \\
\text { reverse grading also occurs. } \\
\text { Clast or matrix-supported. } \\
\text { Maximum clast size is }<3 \mathrm{~cm} \\
\text { (average is } 1 \mathrm{~cm} \text { ). Clasts are } \\
\text { angular to subangular. } \\
\text { Rounded pumice clasts } \\
\text { predominate within some beds. }\end{array}$ \\
\hline
\end{tabular}

Facies 3 consists of black to dark gray to gray vitric and volcaniclastic sandstone in beds $1-95 \mathrm{~cm}$ thick, with an average thickness of ca. $20 \mathrm{~cm}$. The sandstone may be bioturbated where it is overlain by Facies 1 or 2 . Convoluted intervals $3-85 \mathrm{~cm}$ thick, with water-escape pipes, microfaults, and overturned foresets, are common. The convolutions may extend throughout sandstone beds up into overlying siltstone or are confined within layers. Facies 3 can be subdivided into (1) normally graded, but otherwise structureless sandstone (Subfacies 3a); (2) trough cross-stratified sandstone (Subfacies 3b); (3) planar, wavy, wedge-planar, and lenticular laminated sandstone (Subfacies $3 \mathrm{c}$ ); and (4) trough cross-laminated sandstone (Subfacies 3d) (Table 1).

Facies 4 consists of volcaniclastic breccia and volcanic conglomerate. The characteristics of this facies are summarized in Table 1, but some points should be mentioned. Within beds dominated by gray pumice clasts, the clasts commonly increase in size upward (coarsetail reverse grading), whereas the matrix is normally graded (fine-tail normal grading) (Fig. 7). The conglomerate bed in Core 135-840B$60 \mathrm{X}$ is unusual in that it contains a polymict assemblage of subangular 
$\mathrm{cm}$

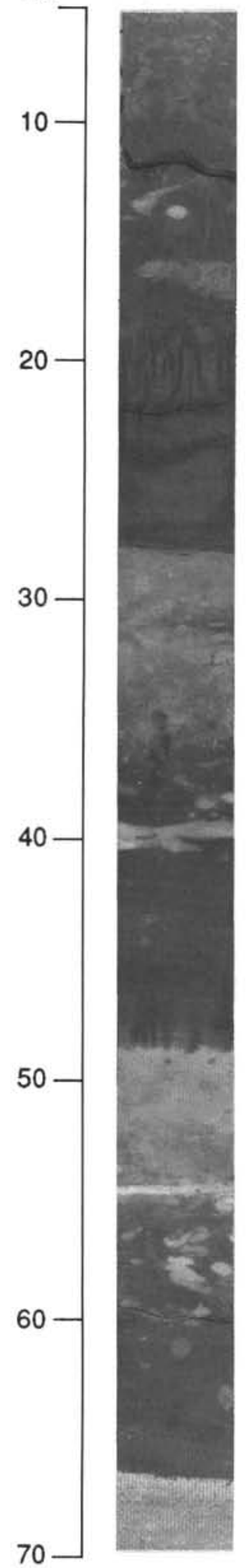

70

Figure 4. Core photograph showing three volcaniclastic turbidites (dark gray) overlain by pelagic/hemipelagic sediments (light gray). Note water-escape pipes at $20 \mathrm{~cm}$ and bioturbation extending down into the volcaniclastic lithologies. Section 135-840B-45X-2, 5-70 cm.
135-840B-52X

${ }_{4814}^{m b s t}$

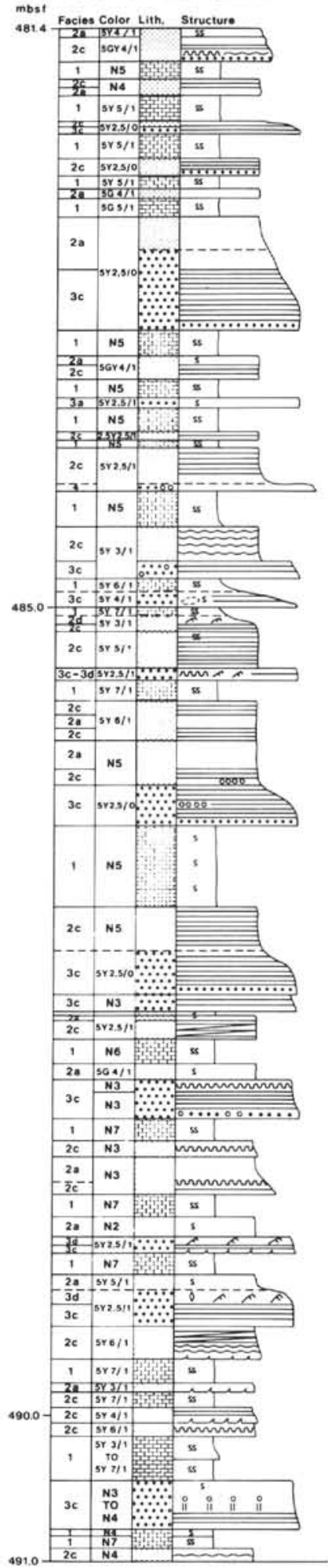

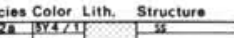

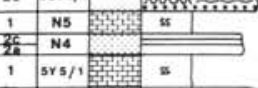

3res/otion

$15 r s / 1$

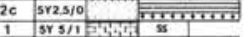

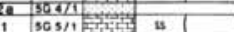

NS

1 N

$2 c$ sr2.s/

1

$2 \mathrm{c}$

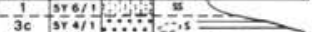

$2 \mathrm{e}$ srsi

$3 c-30$ sra.s/

\begin{tabular}{|l|l|}
\hline$\frac{1}{2 c}$ & $5 x$ \\
\hline $2 a$ & $5 x$ \\
\hline 25 & \\
\hline
\end{tabular}

2a

$2 c$

1

2e N

c N3 $\ldots \ldots$

Ne Frisis s

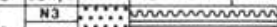

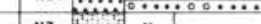

N3 H mmmman

(a)

1

2. $\mathrm{N}^{2}$ का

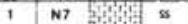

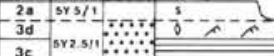

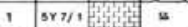

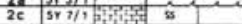

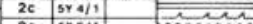

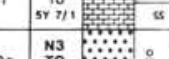

$\frac{1}{1}$

Figure 5. Representative stratigraphic section through part of Unit III. Cores $135-840 \mathrm{~B}-52 \mathrm{X}$ and $-53 \mathrm{X}$ (481.4-497.3 mbsf).
$135-840 B-53 X$

mbsi facies colof Lith. Structure

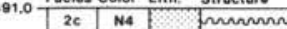

- miminimans

sras.

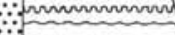

$\because 6 . . .000$

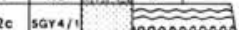

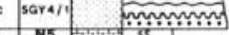

sकरा . . . .......

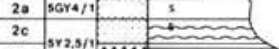

3e ${ }^{\text {sv } 2,5 / 1, \ldots \ldots \ldots \ldots \ldots}$

1 N6

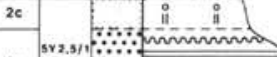

40.000 .0000

1. NS

2a. N4

sदर का का
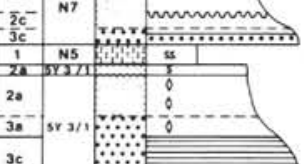

3

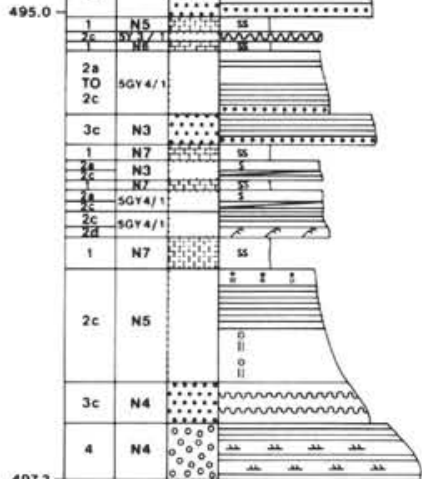

LEGEND

Clond Claystone - Facies 1

Siltstone - Facies 2

Sandstone - Facies 3

$0 \%$ Conglomerate - Facies 4

- Sharp contact

-.. Gradational contact

e. Load casts

Planar laminae

$\approx \approx$ Wavy laminae

Wedge planar laminae

e- Lenticular lamina

- Cross-laminate

1. Cross bedded

mun Convoluted bedding

Water escape structure

Isolated pobbles

Slight bioturbation

- Heavy bioturbation
20.5 
$\mathrm{cm}$
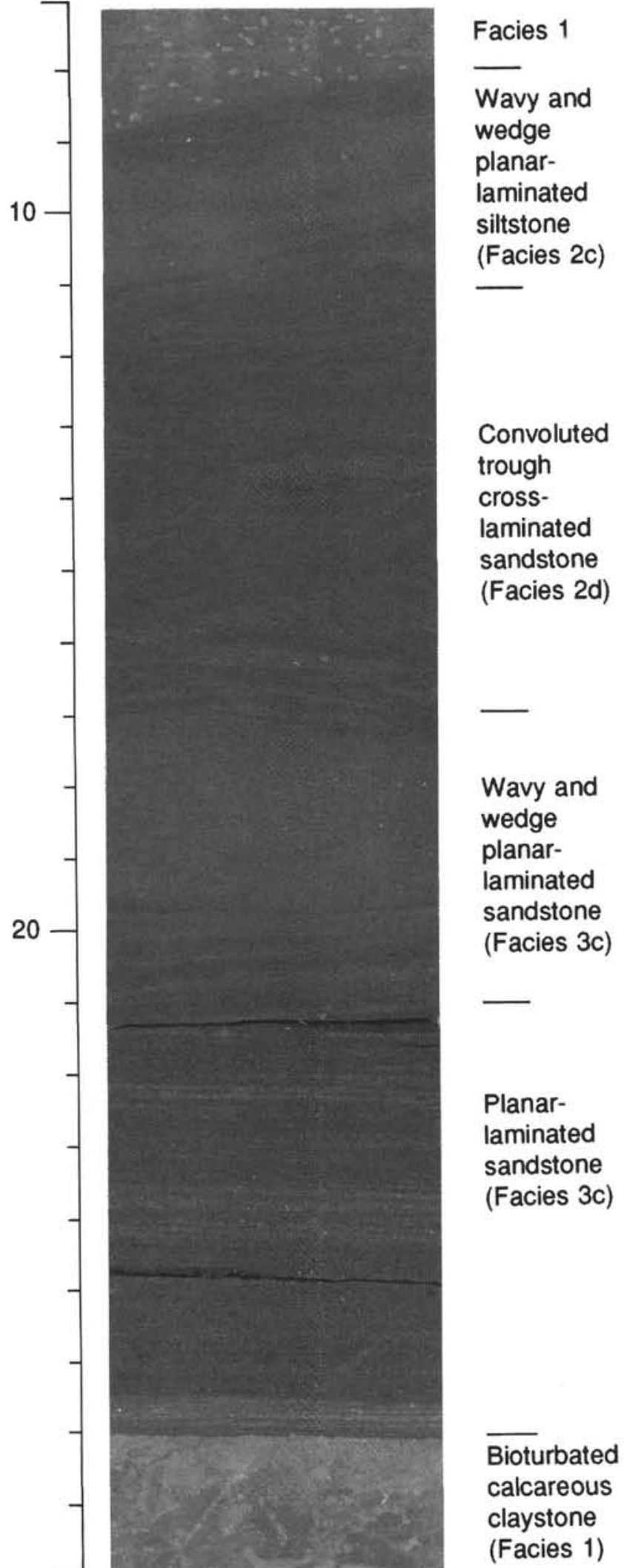

Figure 6. Core photograph showing a commonly occurring facies sequence. Planar-laminated sandstone (Subfacies $3 \mathrm{c})(27-21 \mathrm{~cm})$ overlain by wavy and wedge planar-laminated sandstone (Subfacies $3 \mathrm{c})(21-17 \mathrm{~cm})$, overlain by convoluted, trough cross-laminated siltstone (Subfacies $2 \mathrm{~d})(17-11 \mathrm{~cm})$, overlain by wavy and wedge-planar laminated siltstone (Subfacies $2 \mathrm{c})(11-8 \mathrm{~cm})$, overlain by bioturbated silty nannofossil mixed sedimentary rock (Facies 1). Section 135-840B-50X-3, 7-29 cm. $\mathrm{cm}$

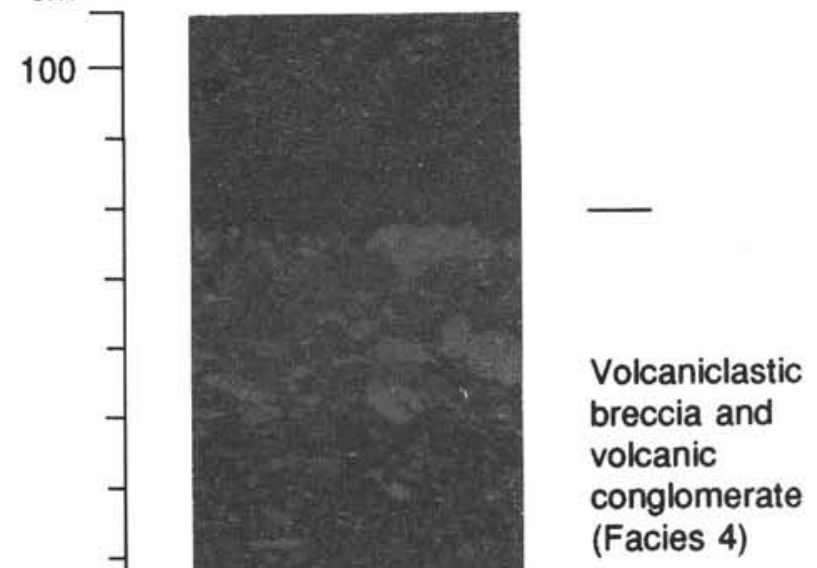

Normally graded sandstone (Facies 3a)

Figure 7. Core photograph showing normally graded, but otherwise structureless sandstone (Subfacies 3a) $(125-111 \mathrm{~cm})$ overlain by volcaniclastic breccia and volcanic conglomerate $(111-102 \mathrm{~cm}$ ) (Facies 4). Note reverse to normal grading in the lower part of the sandstone bed, coarser grained layer with dark-colored volcanic clasts at $115 \mathrm{~cm}$, and coarse-tail reverse grading of pumice clasts in the bed of volcaniclastic breccia and volcanic conglomerate. Section 135-840B-55X-4, 99-127 cm. 
to subrounded gray pumice, red scoriaceous pumice, vein quartz, detrital sulfide, and strongly altered, green, mafic fragments.

\section{Facies Transitions}

Facies 1 (Table 1) overlies Facies 2 or 3 with sharp or gradational contacts (Fig. 5). The upper boundary is usually sharp, planar, or wavy.

Subfacies $2 \mathrm{a}$ occurs, with a gradual transition, beneath Facies 1 or Subfacies 2c. The lower boundary is commonly sharp, planar, or wavy (Fig. 5). Subfacies 2 b usually overlies Subfacies 2a, with a gradational contact. Upward gradations occur from Subfacies $2 b$ into Subfacies $2 \mathrm{c}$ or $2 \mathrm{~d}$. The different lamination types of Subfacies $2 \mathrm{c}$ frequently alternate within a bed, and gradual transitions occur into Subfacies $2 \mathrm{a}, 2 \mathrm{~b}$, and $2 \mathrm{~d}$. Subfacies $2 \mathrm{c}$ commonly grades down into Subfacies $3 \mathrm{c}$, but upward gradations into Facies 1 or Subfacies $2 \mathrm{a}$ are present. Both upper and lower boundaries may, however, be sharp, planar, or wavy. Subfacies $2 \mathrm{~d}$ usually occurs, with gradational boundaries, within beds of Subfacies $2 \mathrm{c}$. Subfacies $2 \mathrm{~d}$ may occasionally directly overlie Subfacies $2 \mathrm{a}$ or $2 \mathrm{~b}$.

Subfacies 3 a generally has a sharp, planar, or wavy base, but it may also grade down into Subfacies $3 \mathrm{c}$ (Fig. 5). Subfacies 3 a usually grades upward into Subfacies $2 a, 3 b$, or $3 c$. Subfacies $3 b$ usually overlies Subfacies $2 \mathrm{a}$, with a gradational contact. Upward gradations occur into Subfacies $3 \mathrm{c}$ or $3 \mathrm{~d}$. Subfacies $3 \mathrm{c}$ commonly overlies Facies 1 with a sharp, planar, or wavy contact. Upward gradations take place into Subfacies 2a, 2c, 3a, or 2d, or a sharp boundary occurs toward Facies 1. Subfacies $3 \mathrm{~d}$ frequently overlies Subfacies $3 \mathrm{c}$, with a gradational contact. Upward gradations are present into Subfacies $2 \mathrm{a}$ or $2 \mathrm{c}$.

Facies 4 usually occur with sharp, erosive contacts overlying finer grained lithologies, but may also occur, with transitional boundaries, within Subfacies 3a, 3b, or 3c. Facies 4 is usually overlain by Subfacies $2 \mathrm{a}, 2 \mathrm{c}$, or $3 \mathrm{c}$.

\section{PETROGRAPHY}

The sedimentary rocks of Unit III consist of volcaniclastic debris, pelagic/hemipelagic components, and diagenetic minerals, the proportion of which varies systematically both within individual turbidites and through the succession. The volcaniclastic debris is immature and dominated by angular and broken glass shards, igneous minerals, and rock fragments; it is generally poorly sorted (Fig. 8). Pumice clasts, both in the pelagic sediments and in the volcaniclastics, are frequently subrounded, however, probably because of abrasion between clasts in floating mats of pumice (e.g., Ballance, 1991). Interparticle pore space in the siltstones and sandstones makes up $20-25 \mathrm{vol} \%$ and much of the section is usually free of cement.

Glass shards are the most abundant constituent of the siltstones and sandstones of Unit III (Fig. 8 and Table 2). These are mostly optically fresh to slightly birefringent; the birefringence is indicative of hydration and slight alteration. Glass shards in the upper part of the unit are dominated by colorless to pale brown dacites, with smaller amounts of dark brown to slightly green basaltic andesites. Below $360 \mathrm{mbsf}$, the majority of the shards are pale greenish brown and of andesitic to dacitic composition (see below).

Other major constituents, in decreasing order of abundance (Table 2), include (1) basaltic, andesitic, and dacitic rock fragments; (2) igneous minerals, mainly plagioclase and light to dark green clinopyroxene (predominantly augite); (3) biogenic grains, mainly foraminifers (Figs. 8-9) and nannofossils, but also radiolarians and sponge spicules; (4) yellowish brown orthopyroxene, olivine, and opaques: (5) small, rhombohedral calcite grains, amphibole, and quartz grains (present only in trace amounts)

At 368-414 mbsf, a zone of alteration and authigenic mineralization occurs in which glass grains are strongly hydrated and the pore spaces are almost completely filled with brown, brownish green, and green smectite. Zeolites, probably natrolite-thompsonite, occur in trace amounts. This zone of alteration was also observed with the gamma-ray

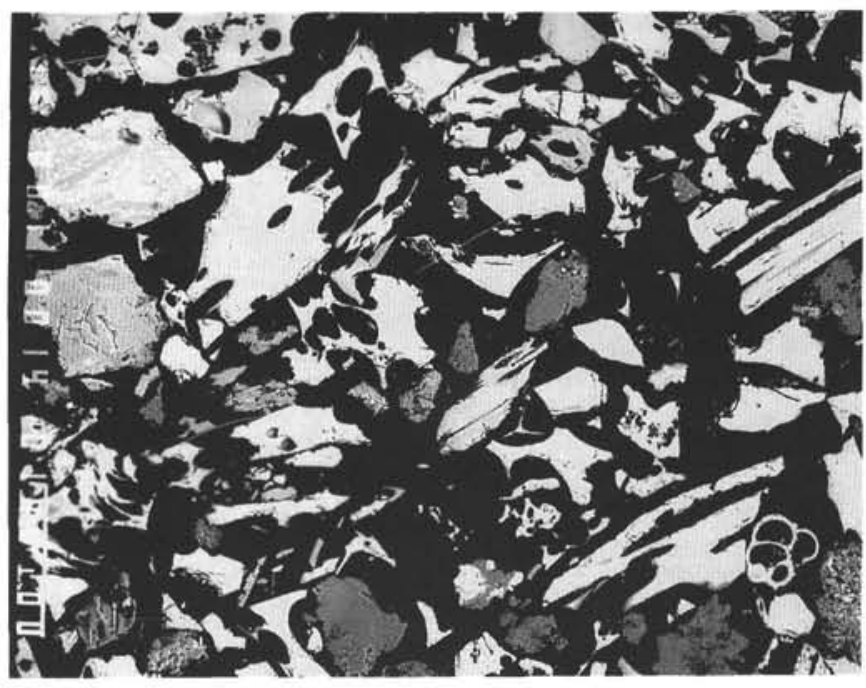

Figure 8. Back-scattered electron photomicrograph of volcaniclastic rock from Unit III. Note poor sorting and immature composition with angular and broken glass shards, igneous minerals, and rock fragments and biogenic grains. Scale bar $=100 \mu \mathrm{m}$. Sample 135-840B-60X-1, 72-77 cm.

tool and the gamma-ray spectrometry tool (Parson, Hawkins, Allan, et al., 1992), and correlates with an increase in sonic velocity and bulk density at $383 \mathrm{mbsf}$. A second zone of intense alteration characterized by cementation by zeolites and clay minerals and changes in physical properties occurs between 559 and $570 \mathrm{mbsf}$. Within this zone all the glass is replaced by pale to dark brown smectite, bright green celadonite, iron hydroxides, and zeolite, probably clinoptilolite/heulandite. Vesicles, interparticle pore space, and veins are also filled with these minerals.

\section{PHASE CHEMISTRY}

Detrital phases within the samples were analyzed by electron microprobe to delineate the character and magmatic affinities of the volcanic source. The analyses were conducted at the Continental Shelf and Petroleum Technology Research Institute A/S on the JEOL Superprobe 733 electron probe microanalyzer with wavelength dispersive spectrometers. Operating conditions were an accelerating voltage of $15 \mathrm{kV}$, a beam current of $15 \mathrm{nA}$, and maximum count times of $10 \mathrm{~s}$. For the analyses, the microprobe beam was defocused to a diameter of $10 \mu \mathrm{m}$. Analyses were corrected using the ZAF 4 correction program. Over 100 microprobe analyses on plagioclase and volcanic glass (e.g. Fig. 9) were conducted. Representative analyses are presented in Tables 3 and 4.

\section{Plagioclase}

Plagioclase feldspar analyses show a range of compositions extending from $\mathrm{An}_{95}$ to $\mathrm{An}_{48}$ (Fig. 10 and Table 3). However, 93\% of the plagioclase grains have greater than $60 \mathrm{~mol} \%$ An. Of the 15 grains analyzed, $13 \%$ are anorthite, $53 \%$ are bytownite, $27 \%$ are labradorite, and $7 \%$ are andesine. Plagioclase grains of albite and oligoclase composition were not encountered. All plagioclase grains have low Or contents, generally $<1.2 \mathrm{~mol} \%$, although one grain has $1.8 \mathrm{~mol} \%$ Or. The overall low Or and high An content of the detrital plagioclase grains indicate derivation from volcanic rocks of low-K tholeiitic compositions.

The compositional range of plagioclase grains is similar to that recorded by Cawood $(1985,1991)$ from Miocene and younger volcaniclastic detritus from the Tonga Ridge south of 'Eua (Fig. 1), and is also similar to the composition of plagioclase grains in volcanic rocks from the active Tofua Arc (Ewart, 1982; Ewart et al., 1973, 1977). 


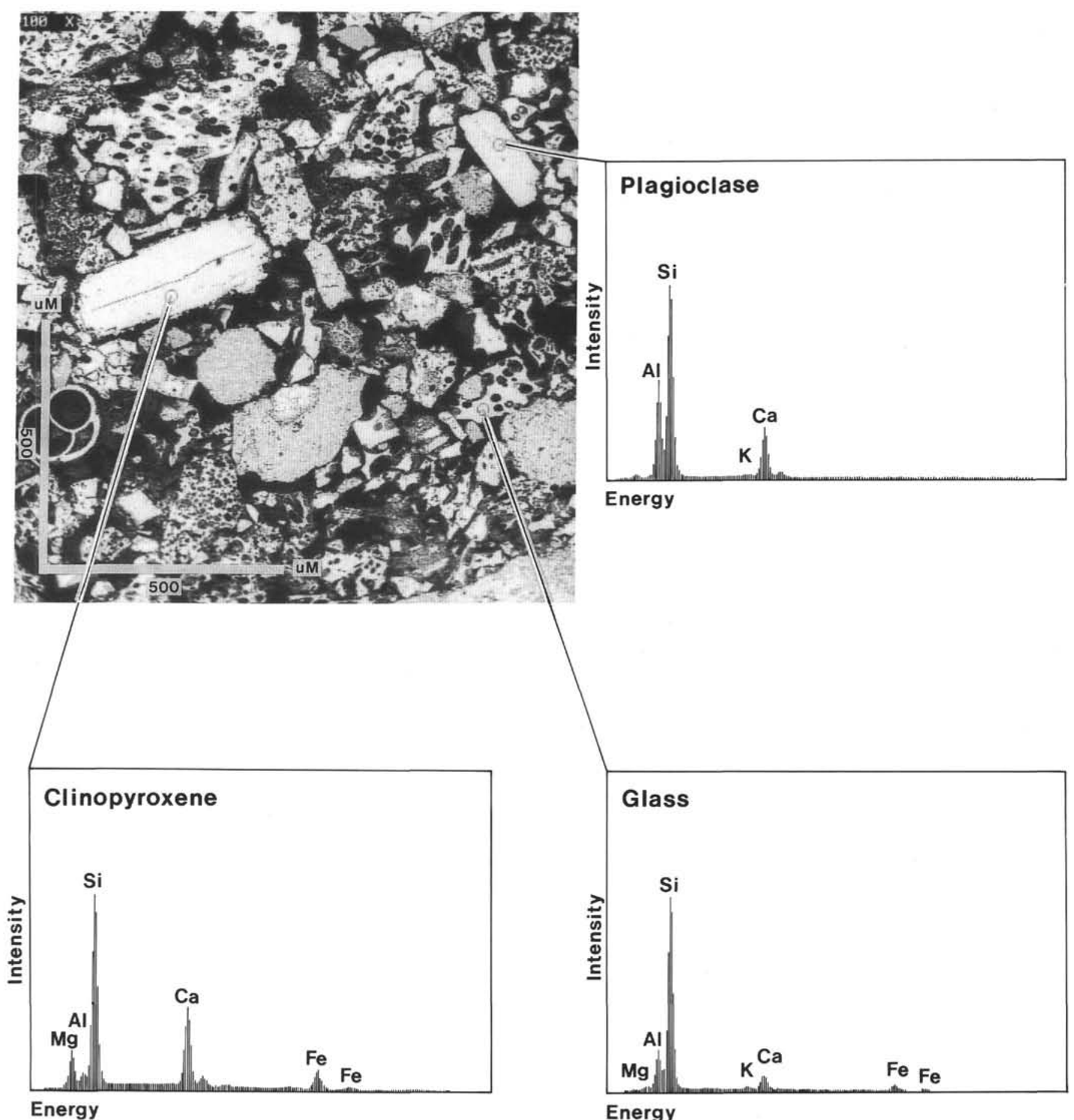

Figure 9. Back-scattered electron photomicrograph of volcaniclastic rock from Unit III (Hole 840B) showing typical energy spectra and intensities for plagioclase, clinopyroxene, and volcanic glass. Note poor sorting, immature composition, and the occurrence of a well-preserved foraminifer. Scale bars $=500 \mu \mathrm{m}$. Sample 135-840B-54X-1, $113-116 \mathrm{~cm}$.

\section{Volcanic Glass}

Volcanic glass is a common product of convergent plate magmatism and reflects the explosive nature of the igneous activity. Analysis of volcanic glass is a direct method of assessing magmatic affinities of the source. Glass occurs in all of the samples analyzed, but not all samples are fresh enough for microprobe analysis. Even in samples containing optically fresh glass, analysis totals are generally low-as low as $86 \%$ (Table 4) - mainly as a result of hydration. Within some intervals, the glass is too altered for microprobe analysis (e.g., in Samples 135-840B-45X-CC, 21-23 cm [417.41 mbsf], and 135-840B$46 \mathrm{X}-2,27-28 \mathrm{~cm}$ [425.62 mbsf]). These samples are in the zones of strong alteration and authigenic mineralization described above. Glass is thermodynamically unstable and is particularly susceptible to alteration because of its amorphous character and its high surface area to volume ratio. The alteration is, however, generally limited to 
Table 2. Petrography of volcaniclastic sandstones from Unit III, Hole 840B.

\begin{tabular}{|c|c|c|c|c|c|c|c|c|c|}
\hline $\begin{array}{l}\text { Core, section, } \\
\text { interval }(\mathrm{cm})\end{array}$ & $\begin{array}{l}\text { Depth } \\
\text { (mbsf) }\end{array}$ & Glass & $\begin{array}{c}\text { Rock } \\
\text { fragments }\end{array}$ & Plagioclase & Clinopyroxene & $\begin{array}{c}\text { Biogenic } \\
\text { grains }\end{array}$ & Orthopyroxene & Olivine & Opaques \\
\hline \multicolumn{10}{|l|}{$135-840 \mathrm{~B}-$} \\
\hline $35 X-2,24-25$ & 329.24 & 72 & 12 & 10 & 1 & 4 & & & 1 \\
\hline $38 \mathrm{X}-1,10-12$ & 347.20 & 86 & 5 & 7 & & $i$ & & & 1 \\
\hline $46 \mathrm{X}-2,27-28$ & 425.62 & $\begin{array}{l}00 \\
68\end{array}$ & 15 & 13 & 1 & 3 & & & \\
\hline $48 X-2,146-147$ & 445.76 & 73 & 9 & 10 & 3 & & 1 & & 4 \\
\hline $51 X-5,119-123$ & 478.89 & 53 & 19 & 15 & 3 & 5 & 2 & 1 & 2 \\
\hline $54 \mathrm{X}-1,113-116$ & 501.83 & 86 & 3 & 5 & 2 & 3 & & & 1 \\
\hline $62 X-7,12-14$ & 587.12 & 80 & 11 & 5 & 2 & & & 1 & $i$ \\
\hline
\end{tabular}

Notes: In addition to the components listed, small calcite grains, amphibole, and quartz grains occur in trace amounts in most of the samples. Percentages were obtained by point counting.

Table 3. Selected microprobe analyses of detrital plagioclase grains from Unit III, Hole 840B.

\begin{tabular}{|c|c|c|c|c|c|c|c|c|c|c|c|c|c|}
\hline $\begin{array}{l}\text { Core, section, } \\
\text { interval }(\mathrm{cm})\end{array}$ & Grain & $\begin{array}{l}\text { Depth } \\
\text { (mbsf) }\end{array}$ & $\mathrm{Na}_{2} \mathrm{O}$ & $\mathrm{MgO}$ & $\mathrm{Al}_{2} \mathrm{O}_{3}$ & $\mathrm{SiO}_{2}$ & $\mathrm{~K}_{2} \mathrm{O}$ & $\mathrm{CaO}$ & $\mathrm{TiO}_{2}$ & $\mathrm{MnO}$ & $\mathrm{FeO}$ & $\mathrm{Cr}_{2} \mathrm{O}_{3}$ & Total \\
\hline \multicolumn{14}{|l|}{$135-840 \mathrm{~B}-$} \\
\hline $33 X-1,6-7$ & 1 & 308.26 & 7.40 & 0.06 & 24.86 & 58.13 & 0.27 & 7.14 & 0.07 & 0.02 & 0.82 & 0.01 & 98.81 \\
\hline $33 X-1,6-7$ & 2 & 308.26 & 2.09 & 0.10 & 32.29 & 48.00 & 0.00 & 15.90 & 0.01 & 0.09 & 0.92 & 0.05 & 99.49 \\
\hline $36 \mathrm{X}-1,103-105$ & 3 & 333.43 & 3.35 & 0.12 & 28.47 & 48.64 & 0.11 & 12.88 & 0.04 & 0.02 & 1.16 & 0.00 & 94.83 \\
\hline $37 X-2,53-54$ & 4 & 339.39 & 0.96 & 0.00 & 35.20 & 45.15 & 0.00 & 18.08 & 0.04 & 0.02 & 0.84 & 0.00 & 100.31 \\
\hline $39 X-1.66-68$ & 5 & 357.46 & 5.65 & 0.01 & 27.29 & 55.55 & 0.07 & 10.13 & 0.05 & 0.02 & 0.53 & 0.00 & 99.33 \\
\hline $46 \mathrm{X}-2.27-28$ & 6 & 425.62 & 3.73 & 0.18 & 29.57 & 52.83 & 0.09 & 12.95 & 0.07 & 0.02 & 0.87 & 0.04 & 100.39 \\
\hline $46 \mathrm{X}-2,27-28$ & 7 & 425.62 & 1.92 & 0.11 & 33.46 & 46.93 & 0.06 & 16.09 & 0.05 & 0.02 & 0.96 & 0.00 & 99.64 \\
\hline $48 X-2,146-147$ & 8 & 445.76 & 5.94 & 0.10 & 26.48 & 57.21 & 0.19 & 9.16 & 0.05 & 0.04 & 0.67 & 0.03 & 99.92 \\
\hline $49 \mathrm{X}-2,123-125$ & 9 & 455.13 & 3.86 & 0.15 & 30.14 & 52.02 & 0.08 & 12.71 & 0.00 & 0.00 & 0.89 & 0.00 & 99.88 \\
\hline $51 X-5,119-123$ & 10 & 478.89 & 1.54 & 0.14 & 32.69 & 46.05 & 0.01 & 17.38 & 0.02 & 0.00 & 0.64 & 0.04 & 98.57 \\
\hline $51 X-5,119-123$ & 11 & 478.89 & 4.51 & 0.11 & 27.26 & 54.89 & 0.10 & 11.38 & 0.01 & 0.02 & 0.84 & 0.00 & 99.16 \\
\hline $51 X-5,119-123$ & 12 & 478.89 & 2.29 & 0.23 & 31.54 & 47.25 & 0.04 & 14.87 & 0.04 & 0.00 & 0.80 & 0.07 & 97.15 \\
\hline $51 X-5,119-123$ & 13 & 478.89 & 4.72 & 0.14 & 26.67 & 55.80 & 0.12 & 11.37 & 0.06 & 0.00 & 0.98 & 0.00 & 99.90 \\
\hline $51 X-5,119-123$ & 14 & 478.89 & 5.39 & 0.07 & 24.90 & 58.48 & 0.17 & 9.30 & 0.14 & 0.00 & 1.18 & 0.00 & 99.66 \\
\hline $62 \times-7,12-14$ & 15 & 587.12 & 5.63 & 0.04 & 28.45 & 55.84 & 0.08 & 9.90 & 0.00 & 0.02 & 0.51 & 0.00 & 100.50 \\
\hline
\end{tabular}

simple hydration, which does not appear to have affected primary igneous trends or element ratios (e.g., Cawood, 1985), although it seems to have diluted absolute element abundances.

The $\mathrm{SiO}_{2}$ content of the glass ranges from $47 \%$ to $72 \%$, covering the compositional range from basalt to rhyolite (Table 4). Within the intervals $308.26-357.46$ and $445.76-587.92 \mathrm{mbsf}$, the silica content decreases upward. An increase in $\mathrm{SiO}_{2}$ content occurs around $400 \mathrm{mbsf}$ (between $357.46-445.76 \mathrm{mbsf}$ ) (Fig. 11). The analyses show normal igneous differentiation trends of decreasing $\mathrm{FeO}, \mathrm{MgO}, \mathrm{CaO}$, and $\mathrm{TiO}_{2}$, and increasing $\mathrm{FeO} / \mathrm{MgO}$ with increasing $\mathrm{SiO}_{2}$ content (Fig. 12). $\mathrm{K}_{2} \mathrm{O}$ does not vary systematically with increasing silica content. The plot of $\mathrm{K}_{2} \mathrm{O}$ vs. $\mathrm{SiO}_{2}$ (Fig. 12) shows that the majority of the analyses fall in the low-K tholeiite field, with some analyses in the mildly, medium-K tholeiite (calc-alkaline) field. On the $\mathrm{FeO} / \mathrm{MgO}$ vs. $\mathrm{SiO}_{2}$ plot (Fig. 12), almost all the samples fall in the tholeiitic field of Miyashiro (1974). On the total alkali-iron-magnesium (AFM) diagram (Fig. 13), all the analyses fall in the tholeiitic field of Irvine and Baragar (1971).

The inter- and intra-sample scatter of major elements probably reflect temporal and spatial changes in magma composition of the igneous source rock (Cawood, 1991). However, alteration and glass hydration may account for some of the scatter within some of the samples. These sedimentary rocks were deposited as turbidites. Therefore, each rock sample may be derived from a source region containing a record of several igneous events, and scatter of detrital glass compositions should be expected. The coherent igneous trend is remarkable, however, and may indicate derivation from a single volcanic source (see below).

\section{FACIES SEQUENCES AND PROCESSES OF DEPOSITION}

Unit III is interpreted as a sequence of volcaniclastic turbidites (Facies 2, 3, and 4) interbedded with pelagic/hemipelagic sediments
(Facies 1) (Fig. 5). Within individual turbidites, decreasing density and velocity and increasing porosity, water content, and void ratio occur from top to base (Parson, Hawkins, Allan, et al., 1992). The decrease in density from top to base reflects the higher content of vitric sand-and gravel-sized particles (with high porosity and high intergranular pore space) within the coarse fraction at the base of each turbidite. The chalks and calcareous siltstones in the tops of turbidites have higher average grain densities.

The turbidites show a variety of facies and facies sequences, and several turbidites showing complete Bouma sequences (Bouma, 1962) occur. These start at the base with a normally graded, but otherwise structureless, interval (Subfacies 2a and 3a or Facies 4) (Bouma Ta) deposited rapidly from suspension with little or no traction transport (e.g., Middleton, 1967), probably from the high-concentration head region of flows that later continued to deposit finer grained sediment from its more dilute body and tail (e.g., Pickering et al., 1989, p. 26).

The normally graded interval is overlain by an upper flow regime, planar laminated or planar stratified, frequently normally graded interval (Subfacies $2 \mathrm{c}$ or $3 \mathrm{c}$ ) (Bouma $\mathrm{Tb}$ ) that resulted from traction sedimentation.

This is overlain by a wavy, wedge-planar, lenticular, trough crosslaminated, or sporadically climbing ripple-laminated interval (Subfacies $2 \mathrm{c}, 2 \mathrm{~d}, 3 \mathrm{c}$, and/or 3d) (Bouma Tc). This is commonly convoluted, especially in the lower part of the unit. Then comes a lower flow regime, planar laminated siltstone interval (Subfacies 2c) (Bouma Td) overlain by bioturbated nannofossil chalk (Facies 1) (Bouma Te). The physical structures within the Bouma Tc and Td intervals are thought to have resulted from suspension fallout and traction from low-concentration turbidity currents (which possibly evolved from turbidity currents intermediate in character during deceleration and deposition. Facies 1 represents accumulation of pelagic and hemipelagic particles in the time periods between the turbidity currents. Similar facies sequences in fine-grained turbidites, with Bouma $\mathrm{Tc}, \mathrm{Td}$, and Te divi- 
Table 4. Microprobe analyses of detrital volcanic glass grains from Unit III, Hole 840B.

\begin{tabular}{|c|c|c|c|c|c|c|c|c|c|c|c|c|c|}
\hline $\begin{array}{l}\text { Core, section, } \\
\text { interval }(\mathrm{cm})\end{array}$ & Grain & $\begin{array}{l}\text { Depth } \\
\text { (mbsf) }\end{array}$ & $\mathrm{Na}_{2} \mathrm{O}$ & $\mathrm{MgO}$ & $\mathrm{Al}_{2} \mathrm{O}_{3}$ & $\mathrm{SiO}_{2}$ & $\mathrm{~K}_{2} \mathrm{O}$ & $\mathrm{CaO}$ & $\mathrm{TiO}_{2}$ & $\mathrm{MnO}$ & $\mathrm{FeO}$ & $\mathrm{Cr}_{2} \mathrm{O}_{3}$ & Total \\
\hline \multicolumn{14}{|l|}{$135-840 \mathrm{~B}-$} \\
\hline $33 X-1,6-7$ & 16 & 308.26 & 3.25 & 4.45 & 14.50 & 55.07 & 0.48 & 7.38 & 1.18 & 0.06 & 10.70 & 0.00 & 96.11 \\
\hline $33 X-1,6-7$ & 17 & 308.26 & 3.12 & 3.49 & 13.85 & 48.18 & 0.60 & 7.12 & 1.49 & 0.17 & 12.10 & 0.00 & 90.17 \\
\hline $33 \times-1,6-7$ & 18 & 308.26 & 1.32 & 3.52 & 15.17 & 55.99 & 0.50 & 7.58 & 1.18 & 0.22 & 11.25 & 0.00 & 96.77 \\
\hline $33 X-1,6-7$ & 19 & 308.26 & 1.65 & 3.50 & 15.08 & 56.50 & 0.47 & 7.29 & 1.20 & 0.29 & 11.35 & 0.00 & 97.38 \\
\hline $33 X-1,6-7$ & 20 & 308.26 & 1.14 & 4.43 & 14.04 & 52.30 & 0.47 & 8.02 & 1.51 & 0.27 & 12.85 & 0.00 & 95.08 \\
\hline $33 \times-1,6-7$ & 21 & 308.26 & 0.69 & 3.45 & 14.40 & 54.42 & 0.46 & 7.39 & 1.19 & 0.26 & 11.21 & 0.00 & 93.52 \\
\hline $33 \times-1,6-7$ & 22 & 308.26 & 1.65 & 3.58 & 15.22 & 56.25 & 0.44 & 7.44 & 1.19 & 0.14 & 11.55 & 0.00 & 97.51 \\
\hline $33 X-1,6-7$ & 23 & 308.26 & 2.79 & 3.49 & 14.90 & 56.41 & 0.44 & 7.30 & 1.27 & 0.23 & 11.50 & 0.00 & 98.37 \\
\hline $36 \times-1,103-105$ & 24 & 333.43 & 1.44 & 4.94 & 14.35 & 54.24 & 0.36 & 8.54 & 1.27 & 0.26 & 12.71 & 0.02 & 98.19 \\
\hline $36 \mathrm{X}-1,103-105$ & 25 & 333.43 & 2.64 & 4.84 & 13.93 & 56.23 & 0.34 & 7.79 & 1.66 & 0.27 & 13.95 & 0.00 & 101.69 \\
\hline $36 \mathrm{X}-1,103-105$ & 26 & 333.43 & 0.13 & 2.20 & 15.64 & 60.86 & 0.24 & 4.85 & 1.24 & 0.13 & 6.97 & 0.04 & 92.35 \\
\hline $36 \mathrm{X}-1,103-105$ & 27 & 333.43 & 0.69 & 2.99 & 15.03 & 55.04 & 0.43 & 6.56 & 1.29 & 0.23 & 9.25 & 0.05 & 91.60 \\
\hline $36 \mathrm{X}-1,103-105$ & 28 & 333.43 & 0.70 & 3.17 & 13.39 & 57.51 & 0.34 & 7.19 & 1.27 & 0.16 & 12.87 & 0.01 & 96.65 \\
\hline $36 \mathrm{X}-1,103-105$ & 29 & 333. & 1.88 & 4.54 & 15.16 & 53.11 & 0.22 & 8.34 & 1.16 & 0.25 & 12.95 & 0.05 & 97.71 \\
\hline $36 \mathrm{X}-1,103-105$ & 30 & 333.43 & 1.14 & 5.23 & 16.97 & 55.19 & 0.28 & 8.67 & 1.11 & 0.33 & 11.85 & 0.06 & 100.88 \\
\hline $36 \mathrm{X}-1,103-105$ & 31 & 333.43 & 2.08 & 5.36 & 15.02 & 50.19 & 0.29 & 8.86 & 1.12 & 0.21 & 12.14 & 0.02 & 95.34 \\
\hline $37 X-2,53-54$ & 32 & 339.39 & 3.14 & 3.63 & 15.51 & 56.28 & 0.36 & 7.52 & 1.22 & 0.19 & 10.52 & 0.01 & 98.41 \\
\hline $37 X-2,53-54$ & 33 & 339.39 & 2.96 & 3.98 & 15.75 & 54.57 & 0.30 & 7.97 & 1.07 & 0.17 & 11.11 & 0.03 & 97.94 \\
\hline $37 X-2,53-54$ & 34 & 339.39 & 3.11 & 2.46 & 13.79 & 61.65 & 0.49 & 5.90 & 1.15 & 0.14 & 8.73 & 0.07 & 97.53 \\
\hline $37 X-2,53-54$ & 35 & 339.39 & 1.68 & 1.32 & 12.66 & 60. & 0.30 & 4.92 & 0.99 & 0.19 & 8.37 & 0.02 & 91.20 \\
\hline $37 X-2,53-54$ & 36 & 339.39 & 2.13 & 4.69 & 12.93 & 53.30 & 0.31 & 9.16 & 0.99 & 0.28 & 15.23 & 0.02 & 99.07 \\
\hline $37 X-2,53-54$ & 37 & 339.39 & 0.65 & 0.46 & 11.65 & 71.53 & 0.32 & 2.66 & 0.42 & 0.04 & 2.60 & 0.06 & 90.43 \\
\hline $39 X-1,66-68$ & 38 & 357 & 2.78 & 2.72 & 13.9 & 58 & 0.41 & & 1.10 & 0.25 & 7.56 & 0.00 & 93.04 \\
\hline $39 X-1,66-68$ & 39 & 357.46 & 3.16 & 2.97 & & & 0.39 & 6.43 & 1.13 & 0.29 & 9.39 & 0.01 & 96.93 \\
\hline $39 X-1,66-68$ & 40 & 357.46 & 3.17 & 3.97 & 13.73 & 55.7 & 0.48 & 7.81 & 1.36 & 0.17 & 11.87 & 0.00 & 98.37 \\
\hline $39 X-1,66-68$ & 41 & 357.46 & 0.10 & 2.75 & 14.74 & 59.30 & 0.15 & 6.10 & 1.09 & 0.23 & 9.22 & 0.03 & 93.75 \\
\hline $39 X-1,66-68$ & 42 & 357.46 & 0.05 & 0.85 & 12.9 & 70.35 & 0.20 & 3.03 & 0.6 & 0.14 & 4.51 & 0.03 & 92.81 \\
\hline $39 \mathrm{X}-1,66$ & 43 & 357.46 & 0.41 & 0.89 & 13.10 & 68.41 & 0.57 & 3.31 & 0.6 & 0.22 & 4.45 & 0.01 & 92.03 \\
\hline $39 X-1,66-68$ & 44 & 357.46 & 2.50 & 7.70 & 12.29 & 55.85 & 0.32 & 7.97 & 0.98 & 0.17 & 12.16 & 0.00 & 99.98 \\
\hline $39 X-1,66-68$ & 45 & 357.46 & 0.60 & 1.87 & 14.13 & 63.40 & 0.46 & 4.84 & 0.81 & 0.20 & 6.06 & 0.00 & 92.41 \\
\hline $39 \times-1,66-68$ & 46 & 357.46 & 0.36 & 1.24 & 13.59 & 62.61 & 0.53 & 3.89 & 0.68 & 0.19 & 5.42 & 0.04 & 88.58 \\
\hline $39 \mathrm{X}-1,66-68$ & 47 & 357.46 & 0.11 & 0.79 & 11. & 66. & 0.46 & 3. & 0.6 & 0.2 & 3.8 & 0.01 & 87.66 \\
\hline $39 X-1,66-68$ & 48 & 357.46 & 0.44 & 1.88 & & & 0.50 & 5.42 & 0.93 & 0.19 & 6.47 & 0.00 & 88.38 \\
\hline $48 X-2,146-147$ & 49 & 445.76 & 1.04 & 8.14 & 13.20 & 51.05 & 0.71 & 1.08 & 1.33 & 0.20 & 15.07 & 0.02 & 91.89 \\
\hline $48 X-2,146-147$ & 50 & 445.76 & 2.84 & 3.41 & 15.13 & 56.18 & 0.67 & 7.34 & 1.22 & 0.18 & 10.99 & 0.08 & 98.08 \\
\hline $48 X-2,146-147$ & 51 & 445 & 2.29 & 3.83 & 14 & 53 & 0.66 & 7.56 & 1.17 & 0.24 & 11.71 & 0.00 & 96.10 \\
\hline $48 X-2,146-147$ & 52 & 445 & 3.12 & 3.89 & & 55 & 0.58 & 7.94 & 1.31 & 0.23 & 12.32 & 0.00 & 99.88 \\
\hline $48 X-2,146-147$ & 53 & 445.76 & 3.34 & 3.62 & 15.13 & 53.74 & 0.64 & 7.55 & 1.29 & 0.24 & 11.54 & 0.04 & 97.17 \\
\hline $48 X-2,146-147$ & 54 & 445.76 & 3.45 & 3.14 & 15.19 & 57.22 & 0.71 & 7.02 & 1.18 & 0.29 & 10.46 & 0.01 & 98.72 \\
\hline $48 X-2,146-147$ & 55 & 445.76 & 3.07 & 3.88 & 15.31 & 54.17 & 0.63 & 7.41 & 1.28 & 0.29 & 12.17 & 0.00 & 98.25 \\
\hline $48 \mathrm{X}-2,146-147$ & 56 & 445.76 & 2.22 & 3.21 & 14.36 & 53.57 & 0.71 & 6.89 & 1.36 & 0.15 & 11.95 & 0.02 & 94.49 \\
\hline $48 X-2,146-147$ & 57 & 445.76 & 3.15 & 3.37 & 15.26 & 54.64 & 0.67 & 7.31 & 1.32 & 0.22 & 11.49 & 0.02 & 97.50 \\
\hline $48 X-2,146-147$ & 58 & 445.76 & 3.42 & 3.21 & 14.94 & 55.51 & 0.80 & 6.99 & 1.32 & 0.19 & 11.03 & 0.00 & 97.44 \\
\hline $51 X-5,119-123$ & 59 & 478.89 & 0.26 & 2.29 & 14.78 & 56.96 & 0.24 & 5.91 & 1.06 & 0.27 & 8.72 & 0.00 & 90.53 \\
\hline $51 X-5,119-123$ & 60 & 478.89 & 0.33 & 1.85 & 13.50 & 61.23 & 0.96 & 4.99 & 0.8 & 0.21 & 6.77 & 0.01 & 90.69 \\
\hline $51 X-5,119-123$ & 61 & 478.89 & 2.17 & 5.05 & 13.27 & 51. & 0.38 & 9.44 & 1.0 & 0.20 & 14.13 & 0.00 & 97.34 \\
\hline $51 X-5,119-123$ & 62 & 478.89 & 0.91 & 1.73 & 13.61 & 62.29 & 1.07 & 4.80 & 0.86 & 0.18 & 6.75 & 0.03 & 92.28 \\
\hline $51 X-5,119-123$ & 63 & 478.89 & 2.68 & 3.62 & 13.50 & 56.39 & 0.57 & 7.95 & 1.22 & 0.33 & 10.75 & 0.00 & 97.03 \\
\hline $51 X-5,119-123$ & 64 & 478.89 & 1.96 & 5.59 & 13.19 & 53.87 & 0.37 & 10.49 & 0.95 & 0.29 & 12.33 & 0.02 & 99.11 \\
\hline $51 X-5,119-123$ & 65 & 478.89 & 2.36 & 5.14 & 13.28 & 53.41 & 0.47 & 9.61 & 0.1 & 0.25 & 13.98 & 0.01 & 99.56 \\
\hline $51 X-5,119-123$ & 66 & 478.89 & 3.15 & 3.51 & 14.71 & & 0.64 & 7.48 & 1.0 & 0.18 & 9.93 & 0.00 & 97.02 \\
\hline $51 X-5,119-123$ & 67 & 478.89 & 0.14 & 0.18 & 11.80 & 70.55 & 1.23 & 1.48 & 0.20 & 0.17 & 2.66 & 0.00 & 88.46 \\
\hline $54 \mathrm{X}-1,113-116$ & 68 & 501.83 & 1.88 & 2.67 & 14.27 & 59.67 & 0.49 & 6.97 & 1.05 & 0.17 & 9.58 & 0.10 & 96.88 \\
\hline $54 X-1,113-116$ & 69 & 501.83 & 1.54 & 2.15 & 13.47 & 60.82 & 0.51 & 5.8 & 0.93 & 0.16 & 8.73 & 0.03 & 94.22 \\
\hline $54 \mathrm{X}-1,113-116$ & 70 & 501.83 & 0.29 & 1.44 & 12.81 & 63.22 & 0.61 & 4.3 & 0.74 & 0.30 & 7.01 & 0.00 & 90.82 \\
\hline $54 \mathrm{X}-1,113-116$ & 71 & 501.83 & 2.30 & 2.86 & 14.44 & & 0.50 & 7.08 & 1.0 & 0.11 & 10.45 & 0.04 & 97.56 \\
\hline $54 \mathrm{X}-1,113-116$ & 72 & 501.83 & 0.24 & 1.74 & 12.97 & 60.75 & 0.48 & 5.28 & 0.91 & 0.24 & 8.45 & 0.03 & 91.15 \\
\hline $54 \mathrm{X}-1,113-116$ & 73 & 501.83 & 2.83 & 3.10 & 14.55 & 57.80 & 0.40 & 7.34 & 0.99 & 0.20 & 10.78 & 0.00 & 98.03 \\
\hline $54 \mathrm{X}-1,113-116$ & 74 & 501.83 & 1.95 & 2.73 & 14.15 & 59.17 & 0.52 & & 1.0 & 0.15 & 9.40 & 0.00 & 95.85 \\
\hline $54 \mathrm{X}-1,113-116$ & 75 & & 3.00 & 2.7 & & & 0.5 & & & 0.20 & 10.04 & 0.01 & 98.14 \\
\hline $54 \mathrm{X}-1,113-116$ & 76 & 501.83 & 2.70 & 2.85 & 14.97 & & 0.50 & 7.22 & 1.00 & 0.22 & 10.78 & 0.00 & 97.88 \\
\hline $54 \mathrm{X}-1,113-116$ & 77 & 501.83 & 2.87 & 2.99 & 14.74 & 57.10 & 0.41 & 7.31 & 1.16 & 0.10 & 10.70 & 0.00 & 97.43 \\
\hline $54 X-1,113-116$ & 78 & 501.83 & 0.27 & 1.86 & 12.56 & 57.48 & 0.55 & 5.41 & 1.02 & 0.19 & 8.99 & 0.00 & 88.38 \\
\hline $62 X-7,12-14$ & 79 & 587.12 & 0.03 & 0.82 & 13.65 & 67.25 & 0.57 & 2.86 & 0.64 & 0.29 & 4.00 & 0.02 & 90.16 \\
\hline $62 X-7,12-14$ & 80 & & 0.40 & 0.68 & 12.72 & & 1.05 & 2.78 & 0.6 & 0.13 & 3.88 & 0.00 & 91.18 \\
\hline $62 \times-7,12-14$ & 81 & 587.12 & 0.46 & 1.09 & 12.94 & & 0.86 & 3.20 & 0.64 & 0.18 & 4.22 & 0.00 & 91.55 \\
\hline $62 \times-7,12-14$ & 82 & 587.12 & 0.06 & 0.88 & 13.07 & 65.87 & 0.49 & 3.06 & 0.67 & 0.15 & 3.68 & 0.08 & 88.06 \\
\hline $62 X-7,12-14$ & 83 & 587.12 & 0.18 & 1.01 & 12.77 & 66.72 & 1.18 & 2.97 & 0.67 & 0.15 & 3.70 & 0.00 & 89.40 \\
\hline $62 X-7,12-14$ & 84 & 587.12 & 0.07 & 0.95 & 13.37 & 64.20 & 0.39 & 3.02 & 0.67 & 0.11 & 4.11 & 0.00 & 86.94 \\
\hline $62 X-7,12-14$ & 85 & & 0.21 & 0.90 & & & 1.31 & 2.80 & 0.61 & 0.21 & 3.67 & 0.05 & 88.14 \\
\hline $62 X-7,12-14$ & 86 & 587.12 & 0.02 & 0.83 & 13.22 & 64.62 & 0.34 & 3.05 & 0.67 & 0.11 & 3.83 & 0.00 & 86.72 \\
\hline $62 X-7,12-14$ & 87 & 587.12 & 0.23 & 0.78 & 12.70 & 67.04 & 1.28 & 2.83 & 0.68 & 0.20 & 3.25 & 0.00 & 89.03 \\
\hline $63 X-1,22-25$ & 88 & 587.92 & 3.87 & 3.98 & 13.31 & 47.36 & 0.39 & 7.14 & 0.99 & 0.23 & 10.88 & 0.00 & 88.20 \\
\hline
\end{tabular}

sions, have been described by Stow and Shanmugam (1980) and Piper (1978) and ascribed to deposition from low-concentration flows.

Depending on grain-size, paleoflow concentration, and paleoflow characteristics (rate of deposition), any of the above-described facies may be absent within individual turbidites. Complete sequences are unusual; top-absent, base-absent, and middle-absent sequences are common (Fig. 5). This has also been described by others (e.g., Stow and Piper, 1984).

Toward the base of some turbidites, in the lower part of the unit (e.g. in Sections 135-840B-50X-4, -55X-4 [Fig. 7], and -62X-5), there are $3-20 \mathrm{~cm}$ intervals of alternating conglomeratic sandstone and conglomerate (Subfacies 3a and Facies 4). Inverse grading from sand- 


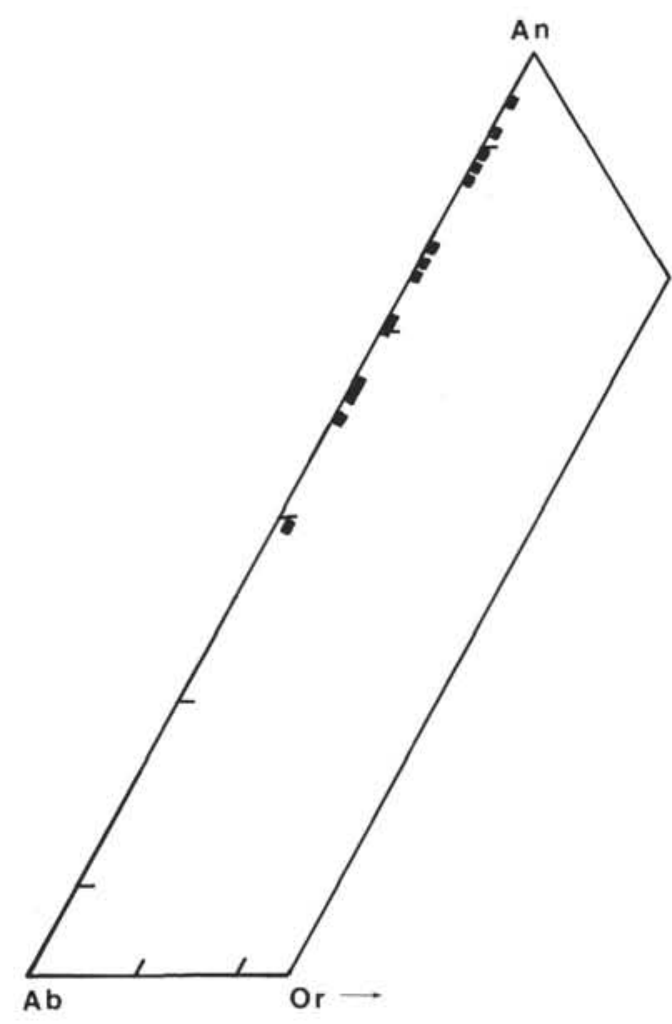

Figure 10. Plagioclase compositions within Unit III $(N=15)$.

stone up into conglomerate is common, and a weak, widely spaced, planar stratification may be developed, probably the result of mixed frictional freezing and suspension sedimentation. This stratification is interpreted to reflect traction carpet (Lowe, 1982) deposition, in which the clasts in the carpet were sheared as a dense dispersion, maintained by dispersive pressure, just above the bed. The intervals of inverse grading are usually overlain by normally graded or stratified conglomerate and pebbly sandstone (Subfacies $3 \mathrm{a}$ and $3 \mathrm{c}$ and Facies 4). The latter are often convoluted and show fluid-escape structures. This interval more or less corresponds to the lowermost divisions of the "classic" Bouma turbidite (Bouma Ta and Tb), although the stratification shows some traction sedimentation. Similar sequences of structures have been described by Walker (1975) and Hein (1982), and are interpreted to reflect rapid deposition from high-concentration turbulent flows as high-density turbidites (see also Einsele, 1991).

The thickest turbidites occur in the lowermost part of Unit III, in Cores 135-840B-56X and -60X. Two of these have exceptionally thick (165 and $195 \mathrm{~cm}$ ) conglomerates (Facies 4) at their base. The conglomerates are erosively based and generally structureless, but show up to 50-cm-thick intervals of inverse and normal grading. The depositional mechanism inferred, using Lowe's (1982) analysis, is one of frictional freezing from high-density turbulent flows with strong clast interaction, yielding coarse-grained, inverse to normally graded, but otherwise structureless beds, with highly packed clasts. These conglomerates were probably deposited from large turbidity currents, which carried coarse sediments farther than the smaller flows. As an alternative, the conglomerates could possibly be interpreted as channel-fill deposits; however, scoured channel margins were not identified in the cores.

The volcaniclastic sediments of Unit III were transported by mass flows out into the forearc basin and possibly through canyons onto the upper trench slope. However, from a study of surface samples from above the mid-slope terrace, Ballance (1991) concluded that in

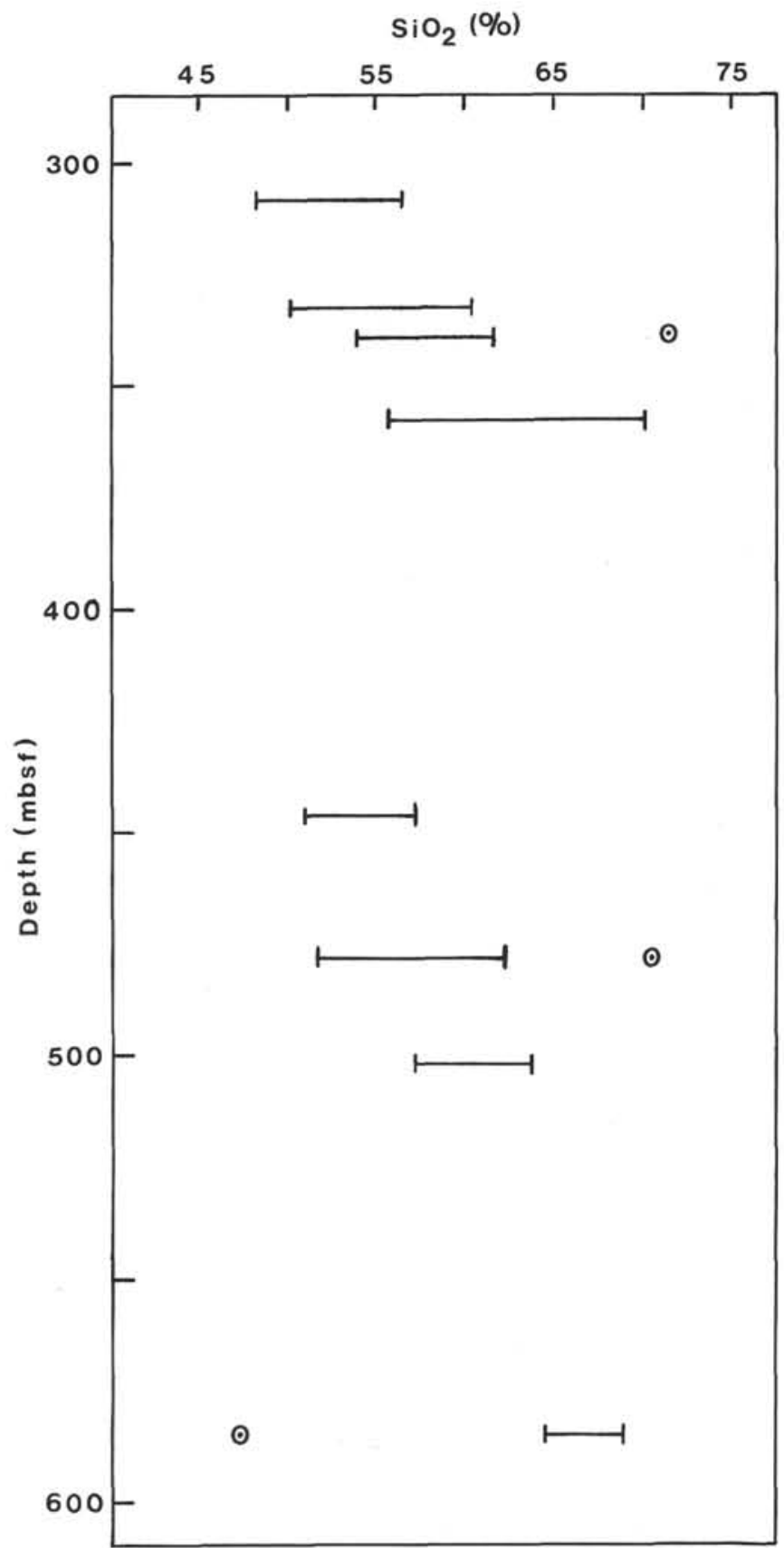

Figure 11. Variation in silica content of volcanic glass vs. depth within Unit III $(N=73)$. Circled points show single analyses with a silica content much higher or lower than the other analyses at that depth. Note the upward-decreasing silica content within the intervals $308.26-357.46$ and $445.76-587.92 \mathrm{mbsf}$, and the increase in silica content around 400 mbsf.

most cases the paleodepth range of the transported faunas overlaps the depth range at which the samples were taken; thus, these deposits represent flows that travelled only a few kilometers downslope.

\section{ENVIRONMENT OF DEPOSITION}

Burrows in the nannofossil chalk of the Zoophycos ichnofacies indicate deposition of Unit III below the photic zone, possibly in bathyal depths (Parson, Hawkins, Allan, et al., 1992). Foraminifers 

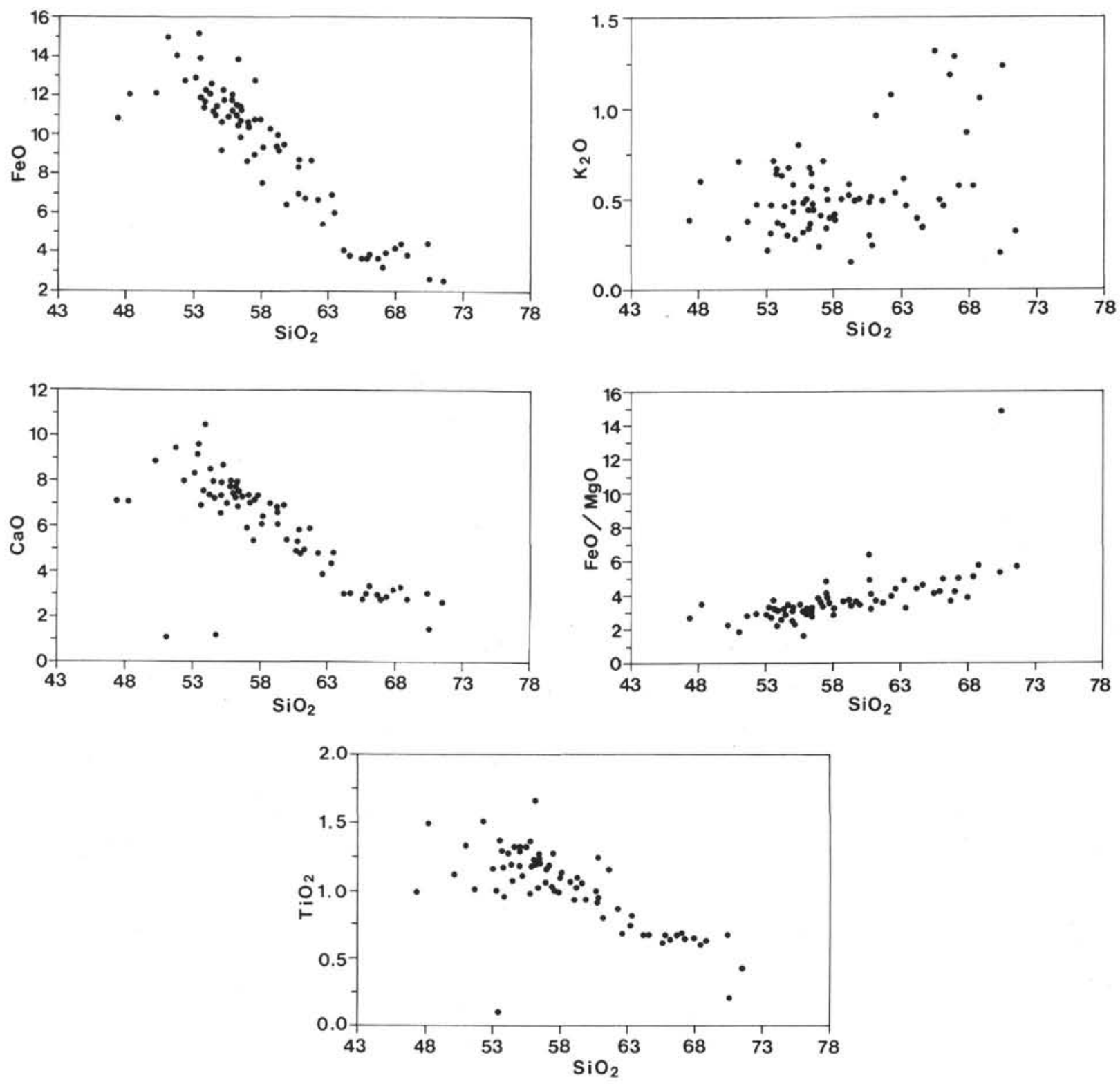

Figure 12. Plot of $\mathrm{FeO}, \mathrm{CaO}, \mathrm{TiO}_{2}$, and $\mathrm{K}_{2} \mathrm{O}$ oxide abundance and $\mathrm{FeO} / \mathrm{MgO}$ ratio vs. silica for Unit $\mathrm{III}$ detrital volcanic glass analyses $(N=73)$.

within the volcaniclastic turbidites are generally well preserved throughout the unit (Nishi and Chaproniere, this volume), indicating water depths during initial deposition comparable with present-day water depths at the site. However, foraminifers within the pelagic intervals show a higher degree of dissolution in the lower part of the unit (Ledbetter and Haggerty, this volume), indicating deposition below the foraminifer lysocline. This suggests a decreasing water depth at the site through the interval of deposition. Greater carbonate dissolution in the lower part would also explain the increase in clay content within the pelagic intervals towards the base of Unit III.

The predominance in the lower part of the unit of relatively thick and coarse-grained turbidites with abundant convoluted bedding indicates rapid deposition from large flows in a setting not far from the source area. Possible explanations for the thinning and fining of turbidites upward through Unit III (Figs. 2 and 3), with less convoluted bedding, could be (1) a change from coarse- to fine-grained sediments being produced in the source area, (2) a change from large to small flows, (3) a change to a more distal flow environment, and/or (4) reduced sediment supply caused by waning volcanic activity in the source area. Reduced volcanic activity could be the result of a westward migration of volcanism, thereby diminishing the gradient to the depocenter. However, the petrology of volcaniclastic grains and the phase chemistry of glass (Tables 3 and 4 ) show no clear systematic variation in the composition (which could result from the westward migration of volcanism) upward through the unit. This, together with the upward-fining trend (Fig. 2), may indicate a decreasing supply of volcaniclastic material from a single, spatially restricted volcanic source, probably a seamount or an island.

Another possible reason for the upward-thinning and -fining of turbidites may have been the creation of physical barriers restricting or partly cutting off sediment supplies. In this tectonically active area, such barriers could originate because of folding or faulting (Site 840 is situated in a heavily faulted region), with the formation of new sub-basins, ridges, and sediment transport channel systems. New 


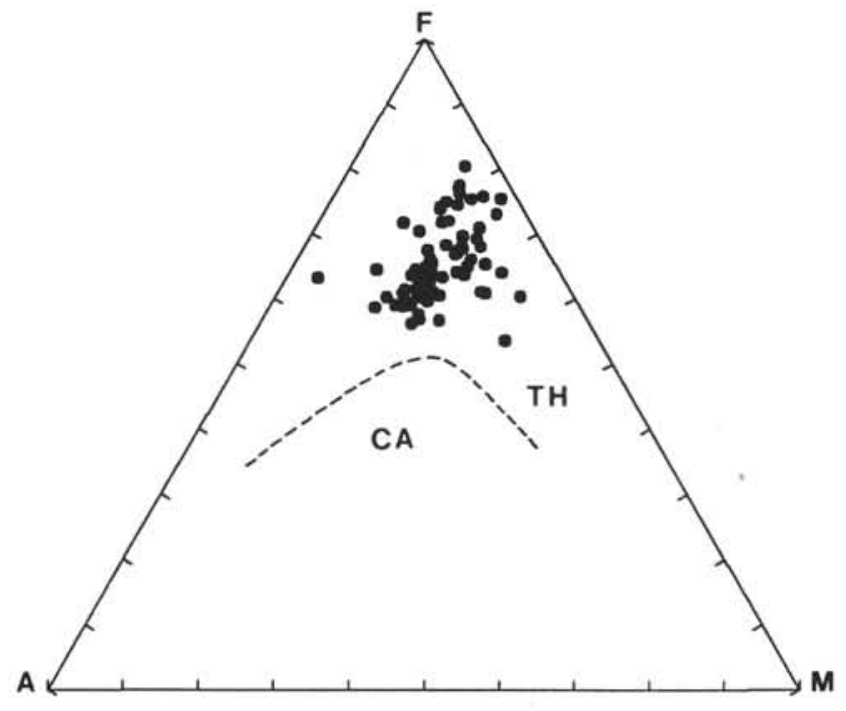

Figure 13. AFM ternary plot of detrital volcanic glass from Unit III. Dashed line separates tholeiitic (TH) and calc-alkali (CA) fields as defined by Irvine and Baragar (1971).

sedimentary sub-basins and ridges could either capture sediments or change the pathways of the major turbidity currents.

The Formation MicroScanner (FMS) dipmeter logs from Site 840 show a steadily increasing dip of the bedding with depth, from an average of approximately $2^{\circ}$ at $260 \mathrm{mbsf}$ to $4.5^{\circ}$ around $500 \mathrm{mbsf}$. The gradual up-sequence decrease in dip is probably the result of progressive syn-depositional tilting of the block on which Site 840 is situated, with growth faulting along east- and north-trending faults (Parson, Hawkins, Allan, et al., 1992).

Many forearc basins contain essentially sheetlike deep-water deposits (Pickering et al., 1989). Interpretation of Unit III as a sheet system sequence is likely, although the abundance of soft-sediment deformation and the absence of positively identified megabeds (ponded turbidites) makes such an interpretation uncertain. Sheet systems typically show an overall coarsening-and thickening-upward trend (Pickering et al., 1989). It should be noted, though, that the fining- and thinning-upward trend within Unit III is probably mainly a result of reduced sediment supply caused by waning volcanism in the source area.

Another possible interpretation of Unit III could be that it represents a slope apron sequence. However, common morphologic elements of slope aprons include gullies, channels, slide scars, slides, and debris-flow masses (Stow, 1986; Pickering et al., 1989). Slope apron deposits also tend to be poorly organized. These elements are rare or do not occur within Unit III, and such an interpretation of Unit III can therefore probably be disregarded.

Interpretation of Unit III as a submarine fan (Mutti and Ricci Lucchi, 1972; Mutti, 1985) sequence is also unlikely, as submarine fans usually occur off rivers where the sediment supply is voluminous. The sediment sources at Site 840 were probably unstable slopes (because of volcanism and tectonism), and odd islands.

The mesoscopic upward-coarsening and-thickening cycles within Unit III (e.g., at 545-525 mbsf; Figs. 2-3) may have originated for several reasons:

1. Increased erosion in the source area following eustatic sealevel fall or tectonic uplift (e.g., Mutti, 1985) may have led to an increasing rate of deposition and possibly progradation of depositional lobes. The individual regressive and transgressive phases observed at Site 840 do not correlate well with the global eustatic cycles (Vail and Hardenbol, 1979; Haq et al., 1987), probably because proc- esses of tectonic subsidence and uplift were more important than eustatic sea-level changes in this area.

2. An increase in volcanic activity could have occurred that would have supplied volcaniclastic material to the source area. This would also have led to an increasing rate of deposition and possibly to progradation.

3. Depositional lobe shifting that could have arisen from subtle lateral shifts in the sites of turbidity-current deposition (e.g., Mutti, 1984 ) or because of tectonic activity with resulting changes in sediment transport pathways.

4. Increasing tectonic activity may have triggered more mass flows and led to progradation of depositional lobes.

Mesoscopic upward-fining and -thinning cycles (e.g., at 500-475 mbsf; Figs. 2-3), may have originated as a result of (1) eustatic sea-level rise or tectonic subsidence, (2) decreased volcanic activity, (3) depositional lobe shifting, or (4) decreasing tectonic activity.

The mesoscopic depositional cycles also appear on the FMS dipmeter data (Parson, Hawkins, Allan, et al., 1992). The scatter of dip magnitudes is generally greater in the coarser grained lithologies in the lower part of the upward-fining cycles and in the upper part of the upward-coarsening cycles, where cross-lamination occurs abundantly. Within these intervals, one can also find cross-stratification and low-angle scours. The FMS dipmeter data show that these structures dip up to $10^{\circ}$. It is not known which of the above-mentioned processes were the most important for the generation of the fining(and/or thinning-) and coarsening- (and/or thickening-) upward cycles within Unit III. However, the varying supply of volcaniclastic material because of changes in the volcanic activity is an important process that has been described by several authors (e.g., Gill, 1976).

Nishi and Chaproniere (this volume) show that the accumulation rate increases from $177 \mathrm{~mm} / \mathrm{k}$.y. below approximately $360 \mathrm{mbsf}$ (ca. $5.3 \mathrm{Ma}$ ) to $866 \mathrm{~mm} / \mathrm{k}$.y. above this depth. This increase is not accompanied by significant changes in the lithology, although an increasing percentage of siltstone occurs in the cores recovered above this depth (Fig. 2). From the biostratigraphic ages (Nishi and Chaproniere, this volume), it is evident that the frequency of turbidite deposition was much higher within the interval from 360 to $260 \mathrm{mbsf}$ (approximately 75 turbidites per 100 k.y.) than below this interval. Thus, the high frequency of turbidite deposition accounts for the high sedimentation rate and may reflect a phase of tectonic instability before the onset of extensive volcanism at $5.25 \mathrm{Ma}$, during the final breakup of the LauTonga Ridge.

From the biostratigraphy and paleomagnetic measurements at Sites 834-839 (Fig. 1), one can see that the oldest sediments in the Lau Basin are approximately 5.6 m.y. old (Parson, Hawkins, Allan, et al., 1992). Unit III covers a time interval of approximately 1.3 m.y., from 6.55 to $5.25 \mathrm{Ma}$; therefore, the sedimentary sequence should be expected to mirror the sequence of igneous and tectonic events at the time of the breakup of the Lau-Tonga Ridge.

\section{CORRELATION WITH REGIONAL GEOLOGICAL HISTORY}

Horizon A, which has been interpreted as a regional, angular, seismostratigraphic unconformity (Herzer and Exon, 1985; Scholl et al., 1985), has been proposed to mark the onset of rifting in the Lau Basin. No pronounced structural or paleontological break was found in the drilled section at a depth corresponding to the observed seismic reflection time for Horizon A (Parson, Hawkins, Allan, et al., 1992). However, at 383 mbsf (approximately $5.5 \mathrm{Ma}$ ), an increase in sonic velocity and bulk density and a drop in total carbonate content takes place (Parson, Hawkins, Allan, et al., 1992). This occurs almost exactly at the interpreted position of Horizon A. Above this depth a marked decrease in the proportion of sandstone in the cores is present, and conglomerates and breccias disappear (Fig. 2). Around $400 \mathrm{mbsf}$ 
an increase in the silica content of volcanic glass also occurs (Fig. 11), and a zone of sediment alteration extends from 368 to about 414 mbsf (see above). Together, these data suggest that Horizon A occurs at 383 mbsf.

Another possible candidate for Horizon A is at $494 \mathrm{mbsf}$, where the FMS data show a sudden increase in the dip of bedding, from ca. $4.5^{\circ}$ above to an average of ca. $10^{\circ}$ below this depth. Below $494 \mathrm{mbsf}$ the dip azimuth is toward the north-northwest; above $494 \mathrm{mbsf}$ the dip azimuth is more toward the north. The dip increase correlates with a marked decrease in velocity and density, recognized in both physical properties and downhole log data. At approximately this depth a change occurs from upward-fining and upward-thinning strata (below $494 \mathrm{mbsf}$ ) to upward-coarsening and upward-thickening strata (Figs. $2-3$ ). The break can probably be explained by faulting, with tilting of the block on which Site 840 is situated.

It has been suggested (Scholl et al., 1985; Herzer and Exon, 1985) that the cause of the Horizon A seismostratigraphic unconformity was uplift, both regional and local, that possibly involved subaerial erosion of the Lau-Tonga Ridge crest. No unconformity (time gap) was found in the drilled section at a depth corresponding to the interpreted position of Horizon A, at 383 mbsf. The diagenetic changes and changes in physical properties observed around $383 \mathrm{mbsf}$ (see above) may possibly be ascribed to a period of slow deposition, during which extensive alteration and strong diagenetic mineralization of the sediments at the seafloor took place. Such an interval of depositional starvation could be interpreted as a condensed section (e.g., Haq et al., 1987).

Westward thickening of the sequence above Horizon A (as seen on seismic reflection profiles) is accomplished in conjunction with eastward onlapping against the structurally and geomorphologically higher Pacific side of the platform (Scholl et al., 1985; Austin et al., 1989). This indicates post-Horizon A subsidence toward the Lau Basin, with the main source region for the sediments located to the west. The decreased proportion of sandstone in the cores and the disappearance of conglomerates and breccias above Horizon A, at Site 840 , may probably be ascribed to a shift of the locus of coarse-grained deposition toward the west. The predominant sediment transport direction during the deposition of Unit III was toward the east and southeast, however (Exon et al., 1985).

The upward-decreasing silica content of volcanic glass within the lower part of Unit III (Fig. 11) can possibly be ascribed to volcanic eruptions from a fractionated magma chamber. The increase in silica content around $400 \mathrm{mbsf}$, followed by upward-decreasing silica content in the upper part of the unit, might reflect a repetition of this process, after the magma chamber had been refilled. Magma might also have been drawn from another, connected magma chamber. The magmatic processes that led to an increase in silica content of volcanic glass occurred at approximately the same time as the tectonic events during formation of seismic reflector Horizon A, and the onset of extensive rifting in the Lau Basin.

In the late Miocene widespread volcanism occurred over much of the Lau-Tonga Ridge (Cole et al., 1985). New data (Clift and Dixon, this volume) suggest that the Tofua Arc originated in the early Pliocene. The volcanic source of the volcaniclastics of Unit III was probably situated, therefore, on the Lau Ridge or on the rifted part of the volcanic arc that is now beneath the seafloor of the Lau Basin.

The volcaniclastics of Unit III are similar to the rocks of the Lau Volcanic Group (LVG) (14-6 Ma old) on the Lau Ridge in that they contain hornblende and common olivines (Exon et al., 1985; Cole et al., 1985). The LVG consists predominantly of andesite-dominated, low-K to medium-K suites (Cole et al., 1985). This is similar to the volcaniclastics of Unit III, which are dominated by low-K tholeiitic rocks, with minor amounts of calc-alkaline debris. It should be noted, however, that the LVG on the southernmost Lau Island, which was closest to Site 840 before the opening of the Lau Basin, consists of a high-K tholeiitic suite (Cole et al., 1985). This suggests that the major volcanic source for the volcaniclastics of Unit III was situated on the rifted part of the volcanic arc. Parson and Hawkins (this volume) have shown that at the latitude of Site 840 only a small proportion of the Lau Basin seafloor was created by seafloor spreading, and that rifted and extended Lau-Tonga Ridge crust accounts for most of the Lau Basin seafloor. The composition of this extended crust (Bednarz and Schmincke, this volume) is very similar to the composition of the volcaniclastics of Unit III. The volcanic source for the volcaniclastics of Unit III was possibly situated to the northwest of Site 840, as indicated by the southward thinning of the seismic section beneath Horizon A (Exon et al., 1985).

Before 5.6 Ma, during the initial rifting of the Lau-Tonga Ridge, sediments accumulated rapidly at Site 840 , and many of the mass flows were deposited from high-density turbidity currents. The sedimentary sequence deposited between 5.6 and 5.3 Ma reflects a quieter period, with rifting and subsidence of the Lau-Tonga Ridge and without extensive volcanism. In the period from 5.3 to $5.25 \mathrm{Ma}$, sedimentation rates increased rapidly, and at the boundary between Units III and II, at approximately $5.25 \mathrm{Ma}$, a change to much more coarse-grained and rapid deposition took place. This is interpreted to reflect the onset of extensive rifting and volcanism in the proto-Lau Basin. Renewed progradation of large volumes of sediments into the forearc basin occurred because of a large supply of volcanic material, and was possibly associated with an uplift in the source area.

\section{CONCLUSIONS}

The sedimentary sequence of Unit III, at Site 840, was deposited in the forearc basin of the Lau Ridge, probably on a slope dominated by sheetlike mass flows. The unit consists of a sequence of volcaniclastic turbidites interbedded with pelagic/hemipelagic sediments. The majority of the turbidites can be classified as Bouma-type, although a change occurs from predominantly high-density turbidites in the lower part of the unit to predominantly low-density turbidites in the upper part of the unit.

Thinning and fining of individual turbidites upward through the unit are interpreted to reflect a decreasing availability of volcanic material in the source area because of decreasing volcanic activity. Decreasing volcanic activity also led to a change from large to smaller flows being shed into the forearc basin.

The composition of detrital glasses ranges from basalt to rhyolite, with the majority of the analyses falling in the low-K tholeiitic field and a few analyses falling in the calc-alkaline field. After initial opening of the Lau Basin around 6.0 m.y. ago, the onset of more extensive rifting, approximately $5.6 \mathrm{~m} . \mathrm{y}$. ago, is reflected by the increased silica content of volcanic glass, although the coherent igneous trend indicates derivation from a single volcanic source. From the composition it is tentatively concluded that this source was situated on the now rifted part of the Lau-Tonga Ridge, within the present Lau Basin.

The influx of thick-bedded and coarse-grained volcaniclastics at the boundary between Units III and II, 5.25 m.y. ago, is interpreted to reflect increasing volcanism and tectonism during the final breakup of the Lau-Tonga Ridge.

\section{ACKNOWLEDGMENTS}

The author would like to thank ODP for the invitation to participate on Leg 135. All the sedimentologists and other participants on board JOIDES Resolution are thanked for their cooperation. The Norwegian Research Council for Science and the Humanities (NAVF) is thanked for the economic support that made it possible for me to participate on the cruise and to do laboratory work. Brian A. Sturt and Rognvald Boyd are thanked for critical comments to an early version of this manuscript, and David Johnson, Douglas G. Masson, and Phil P.E. Weaver are thanked for reviewing the manuscript. Tony Boassen is thanked for his help with the chemical analyses on the electron microprobe, and Irene Lundquist and Bjørg Svendgård are thanked for help in drafting the figures. 


\section{REFERENCES}

Austin, J.A., Taylor, F.W., and Cagle, C.D., 1989. Seismic stratigraphy of the central Tonga Ridge. Mar. Pet. Geol., 6:71-92.

Ballance, P.F., 1991. Gravity flows and rock recycling on the Tonga landward trench slope: relation to trench slope tectonic processes. J. Geol.,99:817-827.

Bouma, A.H., 1962. Sedimentology of Some Flysch Deposits: Amsterdam (Elsevier).

Cawood, P.A., 1985. Petrography, phase chemistry and provenance of volcanogenic debris from the southern Tonga Ridge: implications for arc history and magmatism. In Scholl, D.W., and Vallier, T.L. (Eds.), Geology and Offshore Resources of Pacific Island Arcs-Tonga Region. CircumPac. Counc. Energy Miner. Resour., Earth Sci. Ser., 2:149-170.

, 1991. Nature and record of igneous activity in the Tonga arc, SW Pacific, deduced from the phase chemistry of derived detrital grains. In Morton, A.C., Todd, S.P., and Haughton, P.D.W. (Eds.), Developments in Sedimentary Provenance Studies. Geol. Soc. Spec. Publ. London, 57:305321.

Cole, J.W., Gill, J.B., and Woodhall, D., 1985. Petrologic history of the Lau Ridge, Fiji. In Scholl, D.W., and Vallier, T.L. (Eds.), Geology and Offshore Resources of Pacific Island Arcs-Tonga Region. Circum-Pac. Counc. Energy Miner. Resour., Earth Sci. Ser., 2:379-414.

Einsele, G., 1991. Submarine mass flow deposits and turbidites. In Einsele, G., Ricken, W., and Seilacher, D. (Eds.), Cycles and Events in Stratigraphy: Berlin (Springer-Verlag), 313-339.

Ewart, A., 1982. The mineralogy and petrology of Tertiary-Recent orogenic volcanic rocks: with special reference to the andesite-basaltic compositional range. In Thorpe, R.S. (Ed.), Andesites: New York (Wiley), 25-95.

Ewart, A., Brothers, R.N., and Mateen, A., 1977. An outline of the geology and geochemistry, and the possible petrogenetic evolution of the volcanic rocks of the Tonga-Kermadec-New Zealand island arc. J. Volcanol. Geotherm. Res., 2:205-250.

Ewart, A., Bryan, W.B., and Gill, J.B., 1973. Mineralogy and geochemistry of the younger volcanic islands of Tonga, southwest Pacific. J. Petrol., 14:429-465.

Exon, N.F., Herzer, R.H., and Cole, J., 1985. Mixed volcaniclastic and pelagic sedimentary rocks from the Cenozoic southern Tonga platform and their implications for petroleum potential. In Scholl, D.W., and Vallier, T.L. (Eds.), Geology and Offshore Resources of Pacific Island Arcs-Tonga Region. Circum-Pac. Counc. Energy Miner. Resour., Earth Sci. Ser., 2:75-107.

Gill, J.B., 1976. Composition and age of Lau Basin and Ridge volcanic rocks: implications for evolution of an interarc basin and remnant arc. Geol. Soc. Am. Bull., 87:1384-1395.

Haq, B.U., Hardenbol, J., and Vail, P.R., 1987. Chronology of fluctuating sea levels since the Triassic. Science, 235:1156-1166.

Hawkins, J.W., Bloomer, S.H., Evans, C.A., and Melchior, J.T., 1984. Evolution of intra-oceanic arc-trench systems. Tectonophysics, 102:175-205.

Hein, F.J., 1982. Depositional mechanisms of deep-sea coarse clastic sediments, Cap Enrage Formation, Quebec. Can. J. Earth Sci., 19:267-287.

Herzer, R.H., and Exon, N.F., 1985. Structure and basin analysis of the southern Tonga forearc. In Scholl, D.W., and Vallier, T.L. (Eds.), Geology and Offshore Resources of Pacific Island Arcs-Tonga Region. CircumPac. Counc. Energy Miner. Resour., Earth Sci. Ser., 2:55-73.

Irvine, T.N., and Baragar, W.R.A., 1971. A guide to the chemical classification of the common volcanic rocks. Can. J. Earth Sci., 8:523-548.
Karig, D.E., 1970. Ridges and basins of the Tonga-Kermadec island arc system. J. Geophys. Res., 75:239-254.

Lowe, D.R., 1982. Sediment gravity flows: II. Depositional models with special reference to the deposits of high-density turbidity currents. $J$. Sediment. Petrol., 52:279-297.

Malahoff, A., Feden, R.H., and Fleming, H.S., 1982. Magnetic anomalies and tectonic fabric of marginal basins north of New Zealand. J. Geophys. Res., $87: 4109-4125$.

Middleton, G.V., 1967. Experiments on density and turbidity currents: III. Deposition of sediment. Can. J. Earth Sci., 4:475-505.

Miyashiro, A., 1974. Volcanic rock series in island arcs and active continental margins. Am. J. Sci., 274:321-355.

Mutti, E., 1984. The Hecho Eocene submarine-fan system, south-central Pyrenees, Spain. Geo-Mar. Lett., 3:199-202.

1985. Turbidite systems and their relations to depositional sequences. In Zuffa, G.G. (Ed.), Provenance of Arenites: Dordrecht (D. Reidel), 65-93.

Mutti, E., and Ricci Lucchi, F., 1972. Le torbiditi dell'Apennino settentrional: introduzione all'analisi di facies. Mem. Soc. Geol. Italy, 11:161-199.

Packham, G.H., 1978. Evolution of a simple island arc: the Lau-Tonga Ridge. Aust. Soc. Expl. Geophys. Bull., 9:133-140.

Parson, L., Hawkins, J., Allan, J., et al., 1992. Proc. ODP, Init. Repts., 135: College Station, TX (Ocean Drilling Program).

Pickering, K.T., Hiscott, R.N., and Hein, F.J., 1989. Deep Marine Environments: Clastic Sedimentation and Tectonics: London (Unwin Hyman).

Piper, D.J.W., 1978. Turbidite muds and silts on deep sea fans and abyssal plains. In Stanley, D.J., and Kelling, G. (Eds.), Sedimentation in Submarine Canyons, Fans, and Trenches: Stroudsberg, PA(Dowden, Hutchinson and Ross), 163-176.

Scholl, D.W., Vallier, T.L., and Packham, G.H., 1985. Framework geology and resource potential of the southern Tonga platform and adjacent terranes-a synthesis. In Scholl, D.W., and Vallier, T.L. (Eds.), Geology and Offshore Resources of Pacific Island Arcs-Tonga Region. Circum-Pac. Counc. Energy Miner. Resour., Earth Sci. Ser., 2:457-488.

Stow, D.A.V., 1986. Deep clastic seas. In Reading, H.G. (Ed.), Sedimentary Environments and Facies: London (Blackwell Sci. Publ.), 399-446.

Stow, D.A.V., and Piper, D.J.W., 1984. Deep-water fine-grained sediments: facies models. In Stow, D.A.V., and Piper, D.J.W. (Eds.), Fine-grained Sediments: Deep-Water Processes and Facies: Oxford (Blackwell), 15:611-645.

Stow, D.A.V., and Shanmugam, G., 1980. Sequences of structures in finegrained turbidites: comparison of recent deep-sea and ancient flysch sediments. Sediment. Geol., 25:23-42.

Vail, P.R., and Hardenbol, J., 1979. Sea-level changes during the Tertiary. Oceanus, 22:71-79.

Walker, R.G., 1975. Generalized facies models for resedimented conglomerates of turbidite association. Geol. Soc. Am. Bull., 86:737-748.

Abbreviations for names of organizations and publication titles in ODP reference lists
follow the style given in Chemical Abstracts Service Source Index (published by American Chemical Society).

Date of initial receipt: 27 May 1992

Date of acceptance: 19 November 1992

Ms 135SR-107 